\title{
Relationship between Foreign Macroeconomic Conditions and Asian-Pacific Public Real Estate Markets: The Relative Influence of the US and China
}

\author{
Kim Hiang Liow ${ }^{1, * \mathbb{C}}$, Yuting Huang ${ }^{2}$ and Kai Li Heng ${ }^{1 \mathbb{C}}$ \\ 1 Department of Real Estate, School of Design and Environment, National University of Singapore, \\ Singapore 117566, Singapore; hengkaili1@gmail.com \\ 2 International School of Economic \& Management, Capital University of Economics and Business, \\ Beijing 100070, China; huangyuting0@gmail.com \\ * Correspondence: rstlkh@nus.edu.sg
}

Received: 28 June 2019; Accepted: 25 September 2019; Published: 15 October 2019

\begin{abstract}
The aim of this paper was to examine the relationship between changes in the US and China macroeconomic conditions and the excess returns of nine Asian-Pacific public real estate markets (Singapore, Indonesia, Malaysia, the Philippines, Thailand, Australia, Taiwan, Hong Kong, and Japan). We found that there are insignificant correlations between macroeconomic conditions in the US and China and the real estate markets' excess returns. Additionally, whilst the US macroeconomic factors show stronger causal relationships with the real estate markets in the long run, China's macroeconomic variables have experienced a stronger causal relationship in the short run. Finally, key macroeconomic variables, such as the industrial production output index, long-term interest rates, and economic policy uncertainty, produced fluctuating impulse responses to shocks from the US and China. Overall, we conclude that the US economy continues to have a dominant influence in the Asian-Pacific real estate markets. However, during economic crises and in the short run, the impact of China's economy grows significantly and outweighs that of the US In the context that a high degree of economic and financial integration has affected the interdependent level of international financial markets, the Asian-Pacific securitized real estate markets' performances are also impacted by global shocks.
\end{abstract}

Keywords: Asia-Pacific public real estate markets; macroeconomic variables; economic policy uncertainty; non-linear causality tests; generalized impulse response functions

\section{Introduction}

In recent years, the emergence of $\mathrm{China}(\mathrm{CH})$ as the next global economic superpower has garnered significant attention among economists and investors alike. Along with the economic growth of the Asia-Pacific (APAC) region and financial markets, there is considerable literature on the impact of domestic and foreign macroeconomic factors on the stock markets. However, less academic attention has been rendered regarding the influence of foreign macroeconomic factors on the domestic securitized real estate market, which is an emerging asset class in many APAC economies. ${ }^{1}$ This study examines

1 Real estate investments exist in two main forms: Private real estate and public real estate. While the former refers to physical properties with steady cash flows, the latter is a more liquid and low-cost channel to gain real estate exposure, such as listed real estate companies and real estate investment trusts (known as REITs). Public real estate (the subject of this study) is also commonly referred as "securitized real estate". From this point onward, the terms "securitized real estate", "public real estate", and "real estate" will be used interchangeably throughout the text. 
the relative influence of $\mathrm{CH}$ and the US macroeconomic factors on the APAC securitized real estate markets' excess returns (i.e., risk premia) over the period from January 1998 to April 2017. The US economy is an apparent choice since it is one of the largest markets and an important trading partner of APAC countries.

For many years, APAC stock markets outperformed the US and other developed stock markets regarding equity risk premium (ERP) (Donadelli and Persha 2014; Donadelli and Prosperi 2012). International investors demand an extra ERP because APAC markets are affected by local/regional factors (Donadelli and Prosperi 2012). Another development that happened within the region is that the growing strong linkages between international stock markets and between international bond markets over the past decade prompted investors to search for different opportunities to diversify their portfolios. In this context, real estate investments have emerged to show low correlation with stocks and bonds, and therefore, have appropriate characteristics contributing to portfolio optimization (Schindler 2011). Moreover, the growing financialization of global real estate markets facilitates the allocation of real estate in large multi-asset portfolios to improve asset allocation over the period. Many APAC public real estate has since grown in importance as a destination for international portfolio investment.

Real estate is another important asset class in $\mathrm{CH}$, the US, and many APAC economies. Moreover, many APAC countries are characterized by high population density, massive urbanization growth, lower yield, and relatively high real estate values. Consequently, APAC real estate markets are generally aggressive, with higher total risks and more idiosyncratic risks. Specifically, the US has the world's largest real estate market, which is also the most mature and transparent securitized real estate market. Real estate is one of the biggest recipients of foreign direct investment (FDI) in CH (Fung et al. 2006). With massive urbanization and the growth of private real estate ownership in $\mathrm{CH}$, the scope for Hong Kong (HK) REITs to provide more pure-play property investment opportunities in $\mathrm{CH}$, the mainland China (CH), will grow into an important player in global financial markets (Johansson and Ljungwall 2009), with their direct real estate and securitized real estate markets attracting the interest of domestic and international investors. However, the 2007-2009 global financial crisis (GFC) seriously affected APAC securitized real estate market performances.

Interest in $\mathrm{CH}^{\prime}$ s rising economic influence has come at a time when there is recognition that economic interdependence has also increased in recent decades. The implementation of $\mathrm{CH}^{\prime}$ s belt and road initiative (BRI) (Zheng and Zhang 2016) as an economic corridor is an effort to globally reach out to countries along the route and form a grand diplomatic landscape to strengthen its power relations and international significance (Zheng and Zhang 2016), as well as open its doors to capital inflows and foreign direct investments (FDIs) from other major economies. The GFC and its aftermath made clear that macroeconomic policies in large economies, such as the US, create both real and financial spillovers that can impact economies around the globe. Moreover, $\mathrm{CH}^{\prime}$ s economic reform has gradually shifted toward liberalization of financial markets, and intensified its interactions with global financial markets.

This study is motivated to examine the effects of the economic growth of $\mathrm{CH}$, relative to the US, over the past decade on the performance of the APAC real estate markets in nine selected countries (Singapore, Malaysia, the Philippines, Indonesia, Thailand, Australia, Taiwan, Hong Kong, and Japan). As of 2016, $15 \%$ of the global economy came from CH, but it contributed close to $30 \%$ of the global growth (International Monetary Fund 2017). These figures show that it is critical for stakeholders in the APAC economy and financial markets to recognize that the global economy is moving its direction towards $\mathrm{CH}$ in the future. Moreover, in most economies, there is always latent demand in real assets, which presents significant growth opportunities in financial markets. Policymakers and institutional investors can thus gain meaningful insights from this study on how the growth of the $\mathrm{CH}$ economy can be relied on to forecast the performance of regional and country-specific securitized real estate market returns in the future. In this study, we focus on the causality relationship and shock response between changes in foreign (i.e., the US and $\mathrm{CH}$ ) macroeconomic conditions/uncertainty shocks and APAC securitized real estate market excess return. This analysis is of general interest and has implications 
for real estate portfolio diversification strategies and policy implications, especially on the order of magnitude and direction of the shock impact produced by the level of economic policy uncertainty in the US/CH on the regional securitized real estate markets.

In adding to the existing body of knowledge regarding international financial market integration and economics, one key contribution to the empirical literature on this topic is the use of the new asset class of real estate. Although the public real estate market is a subset of the stock market, it is now considered as an essential asset class that deserves some allocation in mixed-asset portfolios that resembles stock and bond. There is also strong evidence to suggest that public real estate has become increasingly less sensitive to common stocks in developed countries (Ling and Naranjo 2002). Although this topic has received growing attention in the literature (Liow and Adair 2009) and there is some overlap between some earlier studies and the current paper in terms of the methodology employed and the results reported, we believe our present work can be clearly distinguished from the earlier literature by shedding light on the US/CH fundamentals as well uncertainty shocks in the short run or in the long run.

Finally, given the significant market share and the highest levels of securitization in APAC markets, including Australia (AU), Japan (JP), Hong Kong (HK), China (CH), Singapore (SG)and the US, this research on APAC public real estate has significant implications for ongoing international real estate investment strategies, particularly for the US and Asian portfolio managers. This paper is organized as follows. Section 2 provides a brief literature review and identifies the literature gap. Section 3 explains data requirement and is followed by Section 4 , which briefly explains several econometric tests from a lay perspective. Section 5 reports and discusses the results. Section 6 concludes the study with some portfolio and policy implications

\section{Brief Review and Literature Gap}

Prior literature by Ross (1976), Fama (1981) and Chen et al. (1986) found that the relationship between macroeconomic variables and domestic stock returns is significant. Roll and Ross (1980) identified factors that include changes in inflation, industrial production, and the term structure of interest rates as determinants of stock returns. In Latin America, Araújo (2009) observed that the dynamics of real stock returns are mostly affected by macroeconomic shocks. Sharma and Wongbangpo (2002) also found evidence of a significant long- and short-term causal relationship between stock prices of ASEAN5 nations and domestic macroeconomic variables. Nikkinen and Sahlstrom (2004) derived similar conclusions from developed economies on the European stock markets. Finally, Chen et al. (2016) reported that economic policy uncertainty in $\mathrm{CH}$ negatively predicts future stock market returns at various time horizons, which is consistent with the behavioral asset pricing models that feature information uncertainty and investor psychology of inefficient financial markets.

Across the foreign markets, there are mixed results regarding the contributing effects of macroeconomic factors on stock returns. Nikkinen and Sahlstrom (2004) contend that firms and economies operating in several markets are interested in the economic condition of the US market, as it is one of the largest markets and an important trading partner of Asian countries. Whilst Binswanger (2004) found that shocks in the industrial production output index can explain the variation of stock prices in the US, European, and Japanese stock markets, Sum (2013) reported a significant adverse effect of US economic policy uncertainty on ASEAN stock returns. Bailliu and Blagrave (2010) found that foreign macroeconomic shocks impact $\mathrm{CH}^{\prime}$ s economy more than advanced economies. Furthermore, Eickmeier and Kuhnlenz (2013) highlighted that global shocks can have a more considerable influence on global inflation dynamics as compared to the macroeconomic shocks that originate from CH. In contrast, Donadelli (2015) as well as Narayan and Narayan (2012) found that there is no correlation between changes in the US macroeconomic variables and Asian stock market excess returns. The weak explanatory power of the US macroeconomic fundamentals suggests that local factors continue to influence Asian stock market prices. The same conclusion can probably be expected from real estate securities since real estate is largely a local business. 
In addition to using the popular correlation analysis, many empirical studies have analyzed the long-term relationship (via co-integration) between foreign financial markets. Cheng and Glascock (2006) showed that the co-integration of stock markets in $\mathrm{CH}, \mathrm{HK}$, and Taiwan with the US became stronger after the 1997 Asia financial crisis (AFC). In India, there is evidence of long-term heteroscedastic relationships between the stock prices and selected macroeconomic variables (Alam 2017). Other examples include Cheng and Yip (2017)'s finding that CH's macroeconomic variables have higher explanatory power on stock market return and volatility in Shanghai and Hong Kong. Within different sub-periods. Li et al. (2015) found a weak causal relationship between the economic policy uncertainty and stock returns in CH and India. However. Chan et al. (1992) found no sign of integration between the stock markets in developed countries in Hong Kong, Japan, Singapore, South Korea, and the US. Finally, Nishimura and Men (2010) found that the CH's stock market had a significant influence on the G5 stock markets but not vice-versa.

From the above review, there is undoubtedly numerous and growing interest in the literature that recognizes the relationship between macroeconomic factors and domestic stock markets, and to a lesser extent, on foreign stock markets. This is especially the case following the increasing degree of co-movement between real and financial variables and financial integration across international stock markets, and the global effects of financial crisis. This study extends the literature to cover another emerging asset class after the AFC: Securitized real estate. As highlighted above, the growth of many APAC public real estate and the strong performance of the $\mathrm{CH}$ economy motivates us to investigate whether APAC real estate excess returns are more influenced by the foreign macroeconomic shocks or by local factors. From a global perspective, public real estate now has emerged into another asset class with different risk-return characteristics from stock and is sensitive to different macroeconomic influences. Consequently, real estate persons, such as global investors and policy makers, should care how this asset class behaves in times of crises to macroeconomic spillover effects in international financial markets, because public real estate markets may have different patterns of causality and impulse response to foreign macroeconomic shocks due to the underlying asset-real estate that can serve as a factor of production and an investment tool (Hui and Ng 2012). This paper aims to stand out from the many papers on the same or similar topics in empirically evaluating the increasing macroeconomic influence from $\mathrm{CH}$ (or otherwise) on APAC real estate markets' excess return performance.

\section{Data}

The study period was from January 1998 to April 2017, the longest period that public real estate returns (in USD) are available for all countries. During this study period, the world experienced at least three major economic/financial crises: 1998-1999 Asian financial crisis, 2007-2008 global financial crisis (GFC), and 2009-2011 European crisis. The full period is further divided into two shorter sample periods: Crisis/pre-GFC period (January 1998-December 2011, which included all three crises) and post-crisis period (January 2012-April 2017). Although we only reported the full-period results for brevity, we analyzed the issues over the two sub-periods and briefly summarize the results in the main text. Table 1 provides the usual descriptive statistics of monthly real estate excess returns (defined as: Real estate returns minus risk-free returns, represented by the 3-month US Treasury Bill rate).

Next, four macroeconomic variables and a real estate market volatility index were used to capture the macroeconomic conditions in the US and $\mathrm{CH}$ and to reflect the production, consumption, and liquidity in these two global economies. This dataset includes the following series: Changes in the industrial production index (IPI), changes in the long-term interest rate (LTINT), changes in the consumer price index $(C P I)$, changes in the money supply aggregate $(M S)$, and the conditional volatility $(\mathrm{CV})$ of the US and $\mathrm{CH}$ stock markets. These macroeconomic risk factors were chosen mainly according to existing empirical studies (Fung et al. 2006; Liow and Adair 2009) on real estate return predictability and a popularly downloaded series from Datastream.

Additionally, the economic policy uncertainty (EPU) constructed by Baker and Davis (2016) was included as another independent variable on a separate model to study the possible effects of US's 
and $\mathrm{CH}^{\prime}$ s EPU on excess returns. As shown in Figure 1, there was increasing uncertainty from 2008 onwards in both economies, which is associated with the 2008 GFC. Interestingly, CH's EPU tracked the US from 1998 to 2011, until 2015 onwards, where its uncertainty increased and rose drastically. The increased uncertainty observed in the $\mathrm{CH}^{\prime}$ s economy in recent years coincides with the period when $\mathrm{CH}$ observed the highest growth rates in the APAC region. Such an observation sets the direction on how the increasing EPU observed in $\mathrm{CH}$ might potentially influence the APAC real estate capital markets. Finally, Table 2 provides a summary of the selected explanatory variables, and Table 3 displays the monthly summary statistics of the US and $\mathrm{CH}$ macroeconomic variables.

Table 1. Statistics of monthly real estate excess returns in APAC markets: 1/1998-4/2007.

\begin{tabular}{cccccc}
\hline Country. & Mean & Std. Deviation & Kurtosis & Skewness & Sharpe Ratio \\
\hline Singapore & 0.001 & 0.112 & 7.141 & -0.095 & 0.006 \\
Malaysia & -0.003 & 0.109 & 6.077 & -0.061 & -0.024 \\
Philippines & 0.005 & 0.11 & 4.326 & -0.226 & 0.042 \\
Indonesia & -0.015 & 0.214 & 20.536 & -0.717 & -0.069 \\
Thailand & 0.006 & 0.189 & 44.21 & 4.18 & 0.029 \\
Australia & -0.001 & 0.072 & 13.995 & -2.151 & -0.01 \\
Taiwan & -0.006 & 0.162 & 45.014 & 4.214 & -0.037 \\
Hong Kong & 0.002 & 0.101 & 6.403 & 0.029 & 0.023 \\
Japan & 0.002 & 0.087 & 3.783 & 0.226 & 0.018 \\
\hline
\end{tabular}

Source: $\mathrm{MSCI}^{2}$ total return indices.

Table 2. Summary of the explanatory variables used in the study.

\begin{tabular}{clc}
\hline Variable & \multicolumn{1}{c}{ Definition and Description } & Expected Sign \\
\hline $\begin{array}{c}\text { Industrial Production Index } \\
\text { (IPI) }\end{array}$ & $\begin{array}{l}\text { It measures the changes in the real output primarily in the } \\
\text { manufacturing sector of an economy, relative to a base year. A } \\
\text { higher level of IPI indicates higher productivity of the } \\
\text { underlying economy and hence will enhance the return } \\
\text { performance of real estate assets. }\end{array}$ & + \\
\hline
\end{tabular}

It refers to the government bond yield with a maturity of 10

years or more. These interest rates are implied by the prices at which the government bonds are traded on financial markets. (LTINT) It is one of the key determinants of investments. With lower interest costs, investment activities may be more attractive, which in turn boost economic growth.

\begin{tabular}{cl}
\hline $\begin{array}{c}\text { Consumer Price Index } \\
\text { (CPI) }\end{array}$ & $\begin{array}{l}\text { An important economic indicator to measure the level of } \\
\text { inflation in an economy. With higher inflation, it will erode the } \\
\text { purchasing power of consumers as well as the overall returns } \\
\text { on assets. }\end{array}$ \\
\hline $\begin{array}{c}\text { Money Supply } \\
\text { (MS) }\end{array}$ & $\begin{array}{l}\text { It has an inverse relationship between interest rates. With } \\
\text { more money circulating in the economy, it will stimulate } \\
\text { investments and will spur economic growth. }\end{array}$ \\
\hline $\begin{array}{c}\text { Conditional Variance } \\
\text { (CV) }\end{array}$ & $\begin{array}{l}\text { CV quantifies our uncertainty about the future observation, } \\
\text { given everything we have seen so far. It is more practical as a } \\
\text { forecast than the volatility of the entire series considered in the } \\
\text { capital markets. }\end{array}$ \\
\hline $\begin{array}{c}\text { Economic Policy Uncertainty } \\
\text { (EPU) }\end{array}$ & $\begin{array}{l}\text { A macroeconomic risk indicator that takes into account the } \\
\text { uncertainty in policies drafted by government agencies and } \\
\text { news reported relating to events of economic uncertainties. }\end{array}$ \\
\hline
\end{tabular}

Source: authors' interpretations based on various sources.

2 MSCI stands for Morgan Stanley Capital International. 


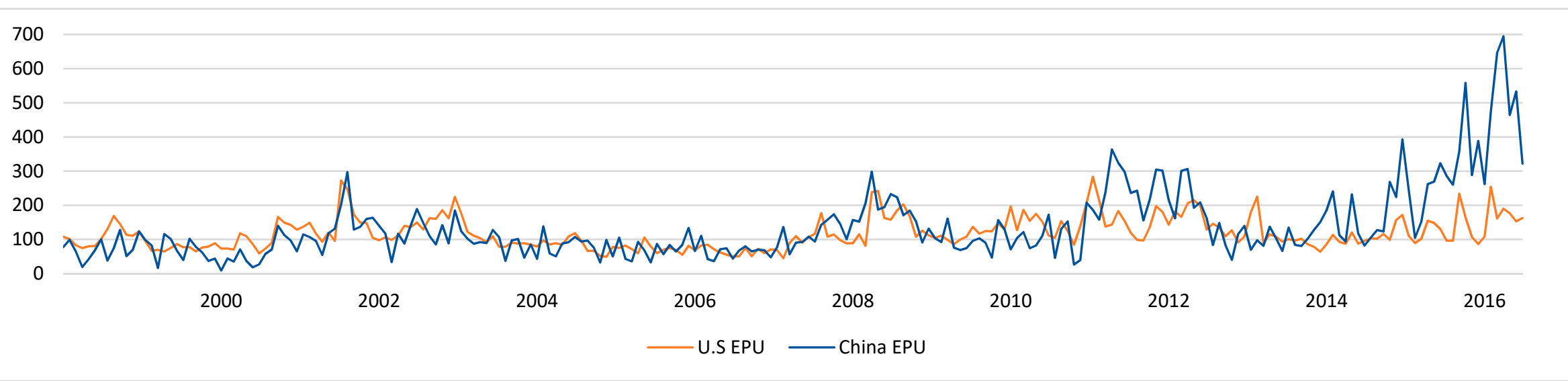

Figure 1. US and China economic policy uncertainty index. Note: This figure reports the records of the US and China monthly economic policy uncertainty index from January 1998 to April 2017 (http://www.policyuncertainty.com). Source: Baker and Davis (2016). 
Table 3. Descriptive statistics of the US and China macroeconomic variables: 1/1998-4/2017.

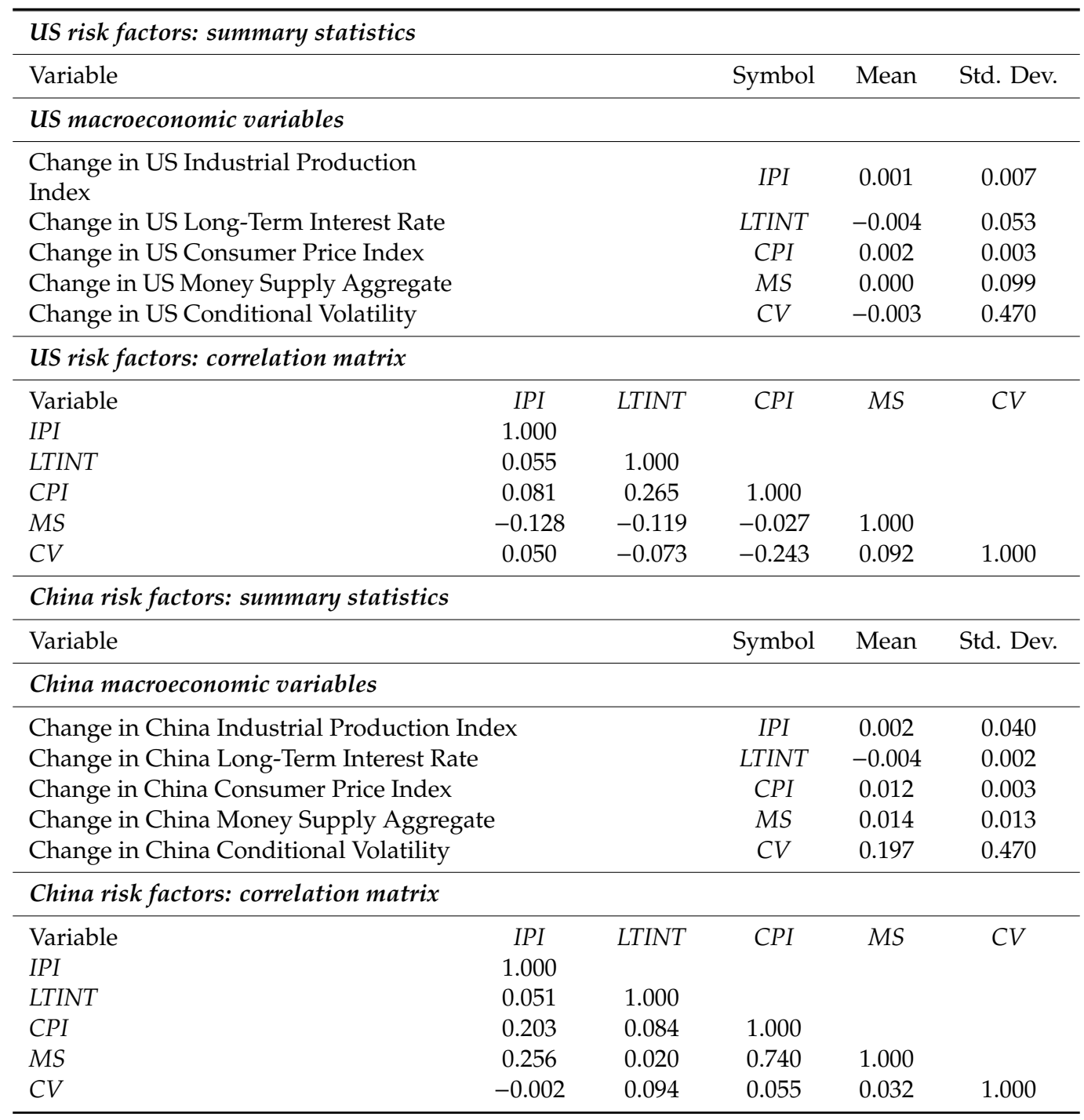

\section{Research Methodology}

We developed several empirical models along predictability, causality, and shock response to examine the dynamic relationship between changes in CH/US's macroeconomic factors on APAC real estate markets' excess returns given.

\subsection{Predictability of Macroeconomic Variables}

Here, a multiple linear beta model (1) was fitted to assess the degree of correlation between the macroeconomic variables and the real estate excess returns:

$$
R E E R_{i, t}=\alpha+\beta_{1} I P I_{t-1}+\beta_{2} \operatorname{LTINT}_{t-1}+\beta_{3} C P I_{t-1}+\beta_{4} M S_{t-1}+\beta_{5} C V_{t-1}+\varepsilon_{t}
$$

where $R E E R_{i, t}$ is the monthly excess return for the $i$ th APAC country at time $t, I P I_{t-1}$ is the change in the industrial production index at time $t-1, L_{T I N T_{t-1}}$ is the change in the 20-year treasury yield (US)/10-year government bond yield (China) at time $t-1, C P I_{t-1}$ is the change in the consumer price index at time $t-1, M S_{t-1}$ is the change in the monetary aggregate M3 (money supply), and $C V_{t-1}$ is the change in conditional volatility in the US and China markets, respectively. 


\subsection{Predictability of Economic Policy Uncertainty (EPU)}

The idea of including EPU as a macroeconomic variable in the analysis came from US-based uncertainty studies undertaken by Bloom (2009) and Baker and Davis (2016). EPU measures the inherent uncertainty of economic policies in a country that arise from a composite of factors, which include the frequency of newspaper coverage, references to policy uncertainty, related keywords, scheduled tax code expirations, and forecaster disagreement about government purchases and inflation. It offers real-time and continuous tracking of policy risk, with the merits of being forward-looking, model-free, and comprehensive to reflect rich information regarding policy uncertainty in the US and $\mathrm{CH}$. To examine whether the level of EPU in the US/CH explained the variation in the APAC REERs, model two was constructed:

$$
R E E R_{i, t}=\alpha+\beta_{6} E P U_{t-1}+\beta_{7} \times\left(W O R L D_{t}\right)+\varepsilon_{t},
$$

where $W O R L D_{t}$ is the MSCI world total stock return at time $t$, and $E P U_{t-1}$ is the natural logarithm of the US and CH EPU index at time $t-1$. With the increasing trend of globalization and financial integration, this variable (WORLD) was included as a control variable to account for the world market risk conditions over the period of analysis.

\subsection{Dynamic Linear and Non-Linear Causality between Macroeconomic Factors/EPU and Excess Returns}

In this section, we evaluate the causal interactions between each of the $\mathrm{CH} / \mathrm{US}$ 's macroeconomic factor/EPU and REERs. As the notion of causality is intrinsically linked to the study of market integration across the whole economy (Okunev et al. 2000), we explored any lead-lag interactions between the macroeconomic variables/EPUs and excess returns. Analysis from this causality analysis also revealed the relative influence of $\mathrm{CH} / \mathrm{US}$ macroeconomic conditions and EPUs in influencing the REERs.

Following the literature, Granger (1969) causality tries to test whether knowing the current and lagged values of (say) CH's inflation improves the forecast of future values of other APAC markets' excess return, and vice-versa. However, the linear causality test, while being very popular in the literature, is sensitive to nonlinearity in the data and structural breaks in the time series relationship due to crises, resulting in possible misleading inferences. Following Baek and Brock (1992)'s test that propose a non-parametric statistical method for uncovering a nonlinear causal relationship, Hiemstra and Jones (1994) modified the test and subsequently was modified again by the $T_{2}$ test statistics of Diks and Panchenko (2006). As in Okunev et al. (2000), this nonlinear Granger causality test was applied to the estimated standardized residual series from the VAR model, which can remove any linear predictive power. Specifically, for two weakly dependent time series, $\left\{E_{x t}\right\}$ and $\left\{Y_{e t}\right\},\left\{X_{t}^{m}\right\}$ denotes the m-length lead vector. The $L_{x}$-length lag vector of $X_{t}$ is denoted by $X_{t-L_{x}}^{L_{x}}=\left(X_{t-L_{x}}, X_{t-L_{x}+1}, \ldots, X_{t-1}\right)$, where $L_{x}=1,2, \ldots, t=L_{x}+1, L_{x}+2, \ldots$ Then, for given values of $\mathrm{m}, L_{x}$ and $L_{y} \geq 1$ and for some $\geq 0, Y$ is said to not strictly Granger cause $X$ if:

$$
\begin{gathered}
\operatorname{Pr}\left(\left\|X_{t}^{m}-X_{s}^{m}\right\|<e \mid\left\|X_{t-L_{x}}^{L_{x}}-X_{s-L_{x}}^{L_{x}}\right\|<e,\left\|Y_{t-L_{y}}^{L_{y}}-X_{s-L_{y}}^{L_{y}}\right\|<e\right) \\
=\operatorname{Pr}\left(\left\|X_{t}^{m}-X_{s}^{m}\right\|<e \mid\left\|X_{t-L_{x}}^{L_{x}}-X_{s-L_{x}}^{L_{x}}\right\|<e\right) .
\end{gathered}
$$

\subsection{Generalized Impulse Response Functions}

Dynamic analysis of VAR models can also be conducted using impulse response functions (IRFs). IRFs graphically display the expected response of each variable to shocks in the variable and shocks of other variables in the system. This function enabled us to characterize the dynamic interactions among variables and permitted us to observe the relative speed of adjustment of the variables in the VAR system. In our case, we appealed to the generalized IRF (GIRF) developed by Pesaran and Shin (1998) to implement the test. 
Specifically, we employed GIRF to investigate the impact of shocks from the macroeconomic factors/EPUs on REERS in a higher dimensional system. Our main objectives were to find out the patterns of response of each real estate market to unexpected return shocks from the macroeconomic factors (IPI, LTINT, CPI, MS, CV, EPU) and thereby provide meaningful interpretations of the initial impact of shocks. Finally, the GIRFs were invariant to the orders of the assets/markets in the VAR system.

\section{Results}

\subsection{Macroeconomic Factors and Excess Returns}

Table 4 reports the estimation results for model one for the full study period. Whilst $\mathrm{CH}$ has a total of eight significant results (interest rate: 1 , inflation: 2, money supply: 4 , and stock market volatility: 1), the US only derives four significant explanatory results (industrial production: 1, inflation: 1, and stock market volatility: 2), with the last column of Table 4 showing the R2 for the multi-factor models. In general, the results indicate that whilst changes in both the US and $\mathrm{CH}$ macroeconomic conditions only weakly explain the variations in REERs, $\mathrm{CH}$ may have a stronger influence on five REERs (SG, MA. IN, TW, and HK) over the US, which is indicated by their marginally higher R2s in the respective regressions. Our relatively low R2 findings are broadly consistent with Donadelli (2015), who found no significant correlation between the US macroeconomic variables and Asian stock prices, and that the Chinese economy was traditionally quite independent from APAC real estate markets. Additionally, the coefficients of the macroeconomic variables for the US and $\mathrm{CH}$ are mostly insignificant in most APAC countries during crisis (January 1998-December 2011) and post-crisis (January 2012-April 2017) periods, results that are partially consistent with Narayan and Narayan (2012) in that US interest rates do not affect Asian stock markets during the crisis period. ${ }^{3}$

Table 4. Regression of the macroeconomic variables of the US and CH on APAC's monthly real estate excess returns: January 1988-April $2017^{4}$.

\begin{tabular}{|c|c|c|c|c|c|c|c|}
\hline \multicolumn{8}{|c|}{ Panel A: US } \\
\hline & & IPI & LTINT & CPI & MS & $\mathrm{CV}$ & \\
\hline Country & Constant & $\beta_{1} I P I_{t-1}$ & $\beta_{2}$ LTINT $_{t-1}$ & $\beta_{3} C P I_{t-1}$ & $\beta_{4} M S_{t-1}$ & $\beta_{5} C V_{t-1}$ & R2 \\
\hline Singapore & -0.002 & -0.292 & -0.03 & 2.149 & 0.003 & -0.01 & 0.007 \\
\hline Malaysia & -0.001 & -0.412 & 0.093 & -0.334 & -0.009 & -0.023 & 0.016 \\
\hline Philippines & -0.001 & -0.274 & -0.176 & 2.22 & 0.052 & $-0.040 * *$ & 0.043 \\
\hline Indonesia & -0.008 & -0.043 & 0.016 & -1.962 & -0.048 & -0.029 & 0.007 \\
\hline Thailand & 0.004 & 1.313 & 0.033 & -0.982 & 0.099 & 0.003 & 0.005 \\
\hline Australia & -0.008 & -0.588 & $-0.203^{* *}$ & $3.771^{* *}$ & -0.048 & $-0.018^{*}$ & 0.061 \\
\hline Taiwan & -0.014 & -0.346 & 0.288 & 5.51 & -0.026 & -0.018 & 0.031 \\
\hline Hong Kong & -0.003 & -1.177 & -0.118 & 3.281 & -0.04 & -0.012 & 0.023 \\
\hline Japan & -0.001 & -0.514 & -0.087 & 1.503 & -0.028 & -0.016 & 0.016 \\
\hline China + & 0.006 & -1.443 & -0.134 & -0.083 & 0.018 & -0.016 & 0.016 \\
\hline \multicolumn{8}{|c|}{ Panel B: China } \\
\hline & & IPI & LTINT & CPI & MS & $\mathrm{CV}$ & \\
\hline Country & Constant & $\beta_{1} I P I_{t-1}$ & $\beta_{2}$ LTINT $_{t-1}$ & $\beta_{3} C P I_{t-1}$ & $\beta_{4} M S_{t-1}$ & $\beta_{5} C V_{t-1}$ & $\mathbf{R} 2$ \\
\hline Singapore & -0.01 & 0.089 & 0.004 & 0.021 & 0.959 & -0.014 & 0.03 \\
\hline
\end{tabular}

3 The sub-period results are not reported in order to conserve space.

4 As highlighted in Footnote 1, this study is concerned with public real estate (securitized real estate), which is part of the stock market and an important asset component in many national economies. As documented in many real estate studies (Fung et al. 2006; Schindler 2011; Ling and Naranjo 2002), since direct (physical) real estate usually respond more slowly to economic stimuli than other financial markets (usually up to three-month lags), it is adequate to assume traded (or public) real estate responds faster, only between one- and two-month delays. 
Table 4. Cont.

\begin{tabular}{|c|c|c|c|c|c|c|c|}
\hline \multicolumn{8}{|c|}{ Panel B: China } \\
\hline & & IPI & LTINT & CPI & MS & $\mathrm{CV}$ & \\
\hline Country & Constant & $\beta_{1} I P I_{t-1}$ & $\beta_{2}$ LTINT $_{t-1}$ & $\beta_{3} C P I_{t-1}$ & $\beta_{4} M S_{t-1}$ & $\beta_{5} C V_{t-1}$ & $\mathbf{R} 2$ \\
\hline Malaysia & $-0.039 * * *$ & -0.004 & -0.176 & $-1.626^{* *}$ & $3.085^{* * *}$ & -0.047 & 0.17 \\
\hline Philippines & -0.013 & -0.24 & 0.032 & -1.058 & $1.878^{* *}$ & -0.019 & 0.041 \\
\hline Indonesia & -0.005 & 0.13 & -0.193 & $1.556^{*}$ & -0.484 & -0.004 & 0.037 \\
\hline Thailand & 0.003 & 0.015 & -0.015 & 0.216 & 0.147 & 0.018 & 0.003 \\
\hline Australia & -0.006 & -0.123 & 0.1 & -0.334 & 0.548 & -0.027 & 0.014 \\
\hline Taiwan & $-0.041^{* *}$ & 0.073 & $0.458 *$ & -1.747 & $3.404 * *$ & 0.01 & 0.06 \\
\hline Hong Kong & -0.015 & 0.01 & -0.016 & -0.089 & $1.318^{* *}$ & -0.018 & 0.049 \\
\hline Japan & -0.008 & -0.025 & -0.043 & -0.615 & 1.009 & -0.01 & 0.016 \\
\hline US + & -0.004 & -0.032 & -0.235 & -0.086 & -0.249 & $-0.086^{* * *}$ & 0.074 \\
\hline
\end{tabular}

\subsection{EPU and Excess Returns}

Estimation results for the roles of US and CH EPU in model two appear in Table 5. As expected,

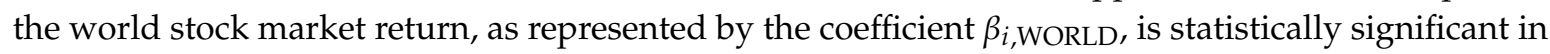
all the APAC real estate markets over the entire period. The US EPU is statistically insignificant in all regressions whilst the CH EPU is able to explain the variation in $\mathrm{PH}, \mathrm{TH}$, and the US's REERs.

Table 5. Linear regression of the APAC REERs on the EPU of the US and China: January 1988-April 2017).

\begin{tabular}{|c|c|c|c|c|}
\hline \multicolumn{5}{|c|}{ Panel A: US } \\
\hline & & EPU & WORLD & \\
\hline Country & Constant & $\beta_{6} E P U_{t-1}$ & $\beta_{7} W O R L D_{t}$ & $\mathbf{R} 2$ \\
\hline Singapore & 0.055 & -0.013 & $1.384^{* * *}$ & 0.334 \\
\hline Malaysia & -0.04 & 0.008 & $0.671^{* * *}$ & 0.08 \\
\hline Philippines & -0.149 & 0.033 & $1.311^{* * *}$ & 0.301 \\
\hline Indonesia & 0.067 & -0.018 & $0.631^{* *}$ & 0.02 \\
\hline Thailand & -0.136 & 0.031 & $1.143^{* * *}$ & 0.078 \\
\hline Australia & 0.026 & -0.007 & $0.978^{* * *}$ & 0.408 \\
\hline Taiwan & 0.065 & -0.016 & $1.008^{* * *}$ & 0.087 \\
\hline Hong Kong & -0.008 & 0.001 & $1.261^{* * *}$ & 0.332 \\
\hline Japan & -0.006 & 0.001 & $0.844^{* * *}$ & 0.203 \\
\hline China + & 0.153 & -0.033 & $0.369 * *$ & 0.031 \\
\hline \multicolumn{5}{|c|}{ Panel B: China } \\
\hline & & EPU & WORLD & \\
\hline Country & Constant & $\beta_{6} E P U_{t-1}$ & $\beta_{7} W_{O R L D}$ & $\mathbf{R} 2$ \\
\hline Singapore & -0.019 & 0.003 & $1.398^{* * *}$ & 0.333 \\
\hline Malaysia & -0.028 & 0.005 & $0.669 * * *$ & 0.08 \\
\hline Philippines & $-0.083^{* *}$ & $0.018^{* *}$ & $1.30^{* * *}$ & 0.305 \\
\hline Indonesia & -0.067 & 0.011 & $0.657^{* *}$ & 0.021 \\
\hline Thailand & -0.16 & $0.035^{* *}$ & $1.152^{* * *}$ & 0.091 \\
\hline Australia & -0.031 & 0.006 & $0.990^{* * *}$ & 0.411 \\
\hline Taiwan & -0.079 & 0.015 & $1.036^{* * *}$ & 0.09 \\
\hline Hong Kong & -0.031 & 0.006 & $1.265^{* * *}$ & 0.334 \\
\hline Japan & -0.005 & 0.001 & $0.844^{* * *}$ & 0.203 \\
\hline US + & $-0.084^{* *}$ & $0.014^{*}$ & 0.007 & 0.016 \\
\hline
\end{tabular}

Notes: cells in shaded areas indicate significance in EPU. ${ }^{* * *},{ }^{* *}$ indicates two-tailed significance at the $1 \%$ and $5 \%$ levels. 


\subsection{Linear Causality Interactions between the Foreign Macroeconomic Variables and APAC's REERs}

This section investigates whether the changes of the US/CH macroeconomic variables can Granger cause the changes in REERs. The full period linear Granger causality results are reported in Table 6 (US) and Table $7(\mathrm{CH})$, respectively. Table 6 indicates different US macroeconomic variables are able to influence all APAC markets in their lead-lag relationships. Therefore, we may conclude that although the US macroeconomic conditions and the APAC REERs are not contemporaneously correlated (see Section 5.1 above), they are causally linked. Specifically, except for Indonesia (IN), eight pairs of linear bilateral causalities exist between changes in the US IPI and REERs. There are an additional three pairs of feedback relationships between changes in the US LINT and REERs in JP and MA, as well as between the US CPI and HK's REER. Similarly, the US economic variables unilaterally Granger cause REERs in SG (3), PH (2), TH (1), TW (3), JP (2), MY (2), IN (1), AU (3), and HK (2). In contrast, CH's macroeconomic variables have weaker causal effects with the APAC's REERs. Inspection of Table 7 indicates that there are a total of only three pairs of feedback relationships and seven unilateral casual relations running mainly from $\mathrm{CH}$ to APAC. Finally, the two sub-period results (not shown to conserve space) indicate that $\mathrm{CH}^{\prime}$ s macroeconomic conditions have produced stronger casual relations with many APAC's REERs during and after the 2008-2009 GFC.

Table 6. Linear Granger-causality test between REERs and the US macroeconomic variables: January 1998-December 2011.

\begin{tabular}{|c|c|c|c|c|c|c|c|c|c|c|c|}
\hline \multicolumn{4}{|c|}{$\begin{array}{l}\text { US Macroeconomic } \\
\text { Variables }\end{array}$} & \multicolumn{2}{|c|}{ Test Values } & & & & & \multicolumn{2}{|c|}{ Test Values } \\
\hline & \multicolumn{3}{|c|}{ Null Hypothesis } & \multirow{2}{*}{$\begin{array}{c}\text { F-Value } \\
4.133\end{array}$} & \multirow{2}{*}{$\frac{p \text {-Value }}{0.017^{* *}}$} & & \multicolumn{3}{|c|}{ Null Hypothesis } & \multirow{2}{*}{$\begin{array}{c}\text { F-Value } \\
2.136\end{array}$} & \multirow{2}{*}{$\frac{p \text {-Value }}{0.097^{*}}$} \\
\hline SG & (IPI) & $\neq>$ & (REER) & & & MY & (IPI) & $\neq>$ & (REER) & & \\
\hline & (REER) & $\neq>$ & (LPI) & 7.061 & $0.001 * * *$ & & (REER) & $\neq>$ & (LPI) & 2.661 & $0.049^{* *}$ \\
\hline & (LINT) & $\neq>$ & (REER) & 6.951 & $0.001^{* * *}$ & & (LINT) & $\neq>$ & (REER) & 3.313 & $0.021 * *$ \\
\hline & (REER) & $\neq>$ & (LINT) & 0.18 & 0.835 & & (REER) & $\neq>$ & (LINT) & 0.347 & 0.791 \\
\hline & $(\mathrm{CPI})$ & $\neq>$ & (REER) & 5.043 & $0.007^{* * *}$ & & $(\mathrm{CPI})$ & $\neq>$ & (REER) & 0.822 & 0.483 \\
\hline & (REER) & $\neq>$ & $(\mathrm{CPI})$ & 0.938 & 0.393 & & (REER) & $\neq>$ & $(\mathrm{CPI})$ & 0.822 & 0.483 \\
\hline & (MS) & $\neq>$ & (REER) & 1.254 & 0.287 & & (MS) & $\neq>$ & (REER) & 0.867 & 0.459 \\
\hline & (REER) & $\neq>$ & (MS) & 0.548 & 0.58 & & (REER) & $\neq>$ & (MS) & 0.353 & 0.787 \\
\hline & $(\mathrm{CV})$ & $\neq>$ & (REER) & 15.86 & $0.000 * * *$ & & $(\mathrm{CV})$ & $\neq>$ & (REER) & 3.162 & $0.025^{* *}$ \\
\hline & (REER) & $\neq>$ & $(\mathrm{CV})$ & 0.479 & 0.62 & & (REER) & $\neq>$ & $(\mathrm{CV})$ & 1.016 & 0.386 \\
\hline \multirow[t]{10}{*}{ PH } & (IPI) & $\neq>$ & (REER) & 3.895 & $0.022 * *$ & IND & (IPI) & $\neq>$ & (REER) & 0.829 & 0.479 \\
\hline & (REER) & $\neq>$ & (LPI) & 7.791 & $0.001^{* * *}$ & & (REER) & $\neq>$ & (LPI) & 1.606 & 0.189 \\
\hline & (LINT) & $\neq>$ & (REER) & 3.253 & $0.041 * *$ & & (LINT) & $\neq>$ & (REER) & 0.407 & 0.748 \\
\hline & (REER) & $\neq>$ & (LINT) & 1.118 & 0.329 & & (REER) & $\neq>$ & (LINT) & 0.624 & 0.6 \\
\hline & $(\mathrm{CPI})$ & $\neq>$ & (REER) & 0.707 & 0.494 & & $(\mathrm{CPI})$ & $\neq>$ & (REER) & 0.302 & 0.824 \\
\hline & (REER) & $\neq>$ & $(\mathrm{CPI})$ & 1.662 & 0.192 & & (REER) & $\neq>$ & $(\mathrm{CPI})$ & 0.052 & 0.984 \\
\hline & (MS) & $\neq>$ & (REER) & 0.605 & 0.547 & & (MS) & $\neq>$ & (REER) & 1.394 & 0.246 \\
\hline & (REER) & $\neq>$ & (MS) & 1.509 & 0.223 & & (REER) & $\neq>$ & (MS) & 0.386 & 0.763 \\
\hline & $(\mathrm{CV})$ & $\neq>$ & (REER) & 8.667 & $0.000^{* * *}$ & & $(\mathrm{CV})$ & $\neq>$ & (REER) & 3.472 & $0.017^{* *}$ \\
\hline & (REER) & $\neq>$ & $(\mathrm{CV})$ & 1.633 & 0.198 & & (REER) & $\neq>$ & $(\mathrm{CV})$ & 0.88 & 0.452 \\
\hline \multirow[t]{10}{*}{ TH } & (IPI) & $\neq>$ & (REER) & 3.538 & $0.031^{* *}$ & AU & (IPI) & $\neq>$ & (REER) & 24.25 & $0.000^{* * * *}$ \\
\hline & (REER) & $\neq>$ & (LPI) & 2.935 & $0.055^{*}$ & & (REER) & $\neq>$ & (LPI) & 18.12 & $0.000 * * *$ \\
\hline & (LINT) & $\neq>$ & (REER) & 2.089 & 0.126 & & (LINT) & $\neq>$ & (REER) & 6.334 & $0.013^{* *}$ \\
\hline & (REER) & $\neq>$ & (LINT) & 0.323 & 0.724 & & (REER) & $\neq>$ & (LINT) & 0.547 & 0.46 \\
\hline & $(\mathrm{CPI})$ & $\neq>$ & (REER) & 1.927 & 0.148 & & $(\mathrm{CPI})$ & $\neq>$ & (REER) & 17.04 & $0.000 * * *$ \\
\hline & (REER) & $\neq>$ & $(\mathrm{CPI})$ & 0.605 & 0.547 & & (REER) & $\neq>$ & (CPI) & 1.28 & 0.259 \\
\hline & (MS) & $\neq>$ & (REER) & 0.245 & 0.783 & & (MS) & $\neq>$ & (REER) & 0.03 & 0.863 \\
\hline & (REER) & $\neq>$ & (MS) & 0.278 & 0.757 & & (REER) & $\neq>$ & (MS) & 4.515 & $0.035^{* *}$ \\
\hline & $(\mathrm{CV})$ & $\neq>$ & (REER) & 3.258 & 0.040 ** & & $(\mathrm{CV})$ & $\neq>$ & (REER) & 42.7 & $0.000 * * *$ \\
\hline & (REER) & $\neq>$ & $(\mathrm{CV})$ & 1.338 & 0.265 & & (REER) & $\neq>$ & $(\mathrm{CV})$ & 1.159 & 0.283 \\
\hline
\end{tabular}


Table 6. Cont

\begin{tabular}{|c|c|c|c|c|c|c|c|c|c|c|c|}
\hline \multicolumn{4}{|c|}{$\begin{array}{l}\text { US Macroeconomic } \\
\text { Variables }\end{array}$} & \multicolumn{2}{|c|}{ Test Values } & \multirow{3}{*}{$\begin{array}{c}\text { Country } \\
\text { HK }\end{array}$} & & & & \multicolumn{2}{|c|}{ Test Values } \\
\hline & \multicolumn{3}{|c|}{ Null Hypothesis } & \multirow{2}{*}{$\begin{array}{c}\text { F-Value } \\
6.062\end{array}$} & \multirow{2}{*}{$\frac{p \text {-Value }}{0.000^{* * *}}$} & & \multicolumn{3}{|c|}{ Null Hypothesis } & \multirow{2}{*}{$\begin{array}{c}\text { F-Value } \\
4.051\end{array}$} & \multirow{2}{*}{$\frac{p \text {-Value }}{0.008^{* * *}}$} \\
\hline TW & (IPI) & $\neq>$ & (REER) & & & & (IPI) & $\neq>$ & (REER) & & \\
\hline & (REER) & $\neq>$ & (LPI) & 2.142 & 0.096 & & (REER) & $\neq>$ & $(\mathrm{LPI})$ & 7.284 & $0.000^{* * *}$ \\
\hline & (LINT) & $\neq>$ & (REER) & 0.969 & 0.381 & & (LINT) & $\neq>$ & (REER) & 10.1 & $0.002^{* * *}$ \\
\hline & (REER) & $\neq>$ & (LINT) & 1.785 & 0.17 & & (REER) & $\neq>$ & (LINT) & 0.266 & 0.607 \\
\hline & $(\mathrm{CPI})$ & $\neq>$ & (REER) & 3.469 & 0.064 * & & (CPI) & $\neq>$ & (REER) & 13.5 & $0.000^{* * *}$ \\
\hline & (REER) & $\neq>$ & $(\mathrm{CPI})$ & 2.389 & 0.124 & & (REER) & $\neq>$ & $(\mathrm{CPI})$ & 2.736 & $0.100 *$ \\
\hline & (MS) & $\neq>$ & (REER) & 5.026 & $0.000^{* * *}$ & & (MS) & $\neq>$ & (REER) & 0.386 & 0.68 \\
\hline & (REER) & $\neq>$ & (MS) & 0.93 & 0.493 & & (REER) & $\neq>$ & (MS) & 0.925 & 0.398 \\
\hline & $(\mathrm{CV})$ & $\neq>$ & (REER) & 2.964 & $0.004^{* * *}$ & & $(\mathrm{CV})$ & $\neq>$ & (REER) & 34.7 & $0.000^{* * *}$ \\
\hline & (REER) & $\neq>$ & $(\mathrm{CV})$ & 0.998 & 0.439 & & (REER) & $\neq>$ & $(\mathrm{CV})$ & 1.588 & 0.209 \\
\hline \multirow[t]{10}{*}{ JP } & (IPI) & $\neq>$ & (REER) & 5.706 & $0.004^{* * *}$ & & & & & & \\
\hline & (REER) & $\neq>$ & (LPI) & 8.462 & $0.000 * * *$ & & & & & & \\
\hline & (LINT) & $\neq>$ & (REER) & 6.289 & $0.002 * * *$ & & & & & & \\
\hline & (REER) & $\neq>$ & (LINT) & 2.487 & $0.086^{*}$ & & & & & & \\
\hline & $(\mathrm{CPI})$ & $\neq>$ & (REER) & 10.359 & $0.002 * * *$ & & & & & & \\
\hline & (REER) & $\neq>$ & $(\mathrm{CPI})$ & 1.252 & 0.264 & & & & & & \\
\hline & (MS) & $\neq>$ & (REER) & 2.004 & 0.137 & & & & & & \\
\hline & (REER) & $\neq>$ & (MS) & 0.802 & 0.45 & & & & & & \\
\hline & $(\mathrm{CV})$ & $\neq>$ & (REER) & 3.32 & 0.021 ** & & & & & & \\
\hline & (REER) & $\neq>$ & $(\mathrm{CV})$ & 1.511 & 0.213 & & & & & & \\
\hline
\end{tabular}

Notes: ${ }^{* * *}, * *, *$ indicates two-tailed significance at the $1 \%, 5 \%$, and $10 \%$ levels. The symbol " $\neq>$ " means "does not Granger-cause".

Table 7. Pairwise linear Granger-causality test between REERs and China's macroeconomic variables: January 1998-December 2011.

\begin{tabular}{|c|c|c|c|c|c|c|c|c|c|c|c|}
\hline \multicolumn{10}{|c|}{ Test Values } & \multicolumn{2}{|c|}{ Test Values } \\
\hline & \multicolumn{3}{|c|}{ Null Hypothesis } & \multirow{2}{*}{$\begin{array}{c}\text { F-Value } \\
1.569\end{array}$} & \multirow{2}{*}{$\begin{array}{c}p \text {-Value } \\
0.212\end{array}$} & \multirow[b]{2}{*}{ MY } & \multicolumn{3}{|c|}{ Null Hypothesis } & \multirow{2}{*}{$\begin{array}{c}\text { F-Value } \\
1.376\end{array}$} & \multirow{2}{*}{$\begin{array}{c}p \text {-Value } \\
0.242\end{array}$} \\
\hline SG & (IPI) & $\neq>$ & (REER) & & & & (IPI) & $\neq>$ & (REER) & & \\
\hline & (REER) & $\neq>$ & (LPI) & 0.264 & 0.608 & & (REER) & $\neq>$ & (LPI) & 0.064 & 0.801 \\
\hline & (LINT) & $\neq>$ & (REER) & 9.195 & $0.003^{* * *}$ & & (LINT) & $\neq>$ & (REER) & 6.872 & $0.000 * * *$ \\
\hline & (REER) & $\neq>$ & (LINT) & 6.599 & $0.011^{* *}$ & & (REER) & $\neq>$ & (LINT) & 1.005 & 0.392 \\
\hline & (CPI) & $\neq>$ & (REER) & 1.569 & 0.212 & & $(\mathrm{CPI})$ & $\neq>$ & (REER) & 1.588 & 0.209 \\
\hline & (REER) & $\neq>$ & (CPI) & 0.264 & 0.608 & & (REER) & $\neq>$ & $(\mathrm{CPI})$ & 0.122 & 0.728 \\
\hline & (MS) & $\neq>$ & (REER) & 0.764 & 0.383 & & (MS) & $\neq>$ & (REER) & 0.969 & 0.426 \\
\hline & (REER) & $\neq>$ & (MS) & 0.24 & 0.624 & & (REER) & $\neq>$ & (MS) & 1.393 & 0.237 \\
\hline & $(\mathrm{CV})$ & $\neq>$ & (REER) & 2.448 & 0.119 & & $(\mathrm{CV})$ & $\neq>$ & (REER) & 0.093 & 0.761 \\
\hline & (REER) & $\neq>$ & $(\mathrm{CV})$ & 0.183 & 0.67 & & (REER) & $\neq>$ & $(\mathrm{CV})$ & 0.002 & 0.962 \\
\hline \multirow[t]{10}{*}{ PH } & (IPI) & $\neq>$ & (REER) & 0.556 & 0.457 & IND & (IPI) & $\neq>$ & (REER) & 0.091 & 0.764 \\
\hline & (REER) & $\neq>$ & (LPI) & 0.057 & 0.811 & & (REER) & $\neq>$ & (LPI) & 0.163 & 0.687 \\
\hline & (LINT) & $\neq>$ & (REER) & 0.27 & 0.763 & & (LINT) & $\neq>$ & (REER) & 1.087 & 0.356 \\
\hline & (REER) & $\neq>$ & (LINT) & 1.588 & 0.207 & & (REER) & $\neq>$ & (LINT) & 0.803 & 0.494 \\
\hline & (CPI) & $\neq>$ & (REER) & 0.013 & 0.91 & & $(\mathrm{CPI})$ & $\neq>$ & (REER) & 0.163 & 0.687 \\
\hline & (REER) & $\neq>$ & (CPI) & 0.234 & 0.629 & & (REER) & $\neq>$ & $(\mathrm{CPI})$ & 0.091 & 0.764 \\
\hline & (MS) & $\neq>$ & (REER) & 1.022 & 0.361 & & (MS) & $\neq>$ & (REER) & 0.86 & 0.489 \\
\hline & (REER) & $\neq>$ & (MS) & 0.688 & 0.504 & & (REER) & $\neq>$ & (MS) & 0.231 & 0.921 \\
\hline & $(\mathrm{CV})$ & $\neq>$ & (REER) & 3.141 & $0.078 *$ & & $(\mathrm{CV})$ & $\neq>$ & (REER) & 1.229 & 0.3 \\
\hline & (REER) & $\neq>$ & $(\mathrm{CV})$ & 0.006 & 939 & & (REER) & $\neq>$ & $(\mathrm{CV})$ & 1.305 & 0.274 \\
\hline \multirow[t]{10}{*}{ TH } & (IPI) & $\neq>$ & (REER) & 0.182 & 0.67 & AU & (IPI) & $\neq>$ & (REER) & 0.049 & 0.824 \\
\hline & (REER) & $\neq>$ & (LPI) & 0.035 & 0.952 & & (REER) & $\neq>$ & (LPI) & 0.496 & 0.482 \\
\hline & (LINT) & $\neq>$ & (REER) & 2.288 & 0.105 & & (LINT) & $\neq>$ & (REER) & 1.008 & 0.367 \\
\hline & (REER) & $\neq>$ & (LINT) & 3.552 & $0.031^{* *}$ & & (REER) & $\neq>$ & (LINT) & 5.115 & $0.007^{* * *}$ \\
\hline & (CPI) & $\neq>$ & (REER) & 0.12 & 0.729 & & $(\mathrm{CPI})$ & $\neq>$ & (REER) & 0.961 & 0.328 \\
\hline & (REER) & $\neq>$ & (CPI) & 0.017 & 0.897 & & (REER) & $\neq>$ & $(\mathrm{CPI})$ & 1.912 & 0.168 \\
\hline & (MS) & $\neq>$ & (REER) & 1.03 & 0.392 & & (MS) & $\neq>$ & (REER) & 0.781 & 0.539 \\
\hline & (REER) & $\neq>$ & (MS) & 1.105 & 0.355 & & (REER) & $\neq>$ & (MS) & 0.573 & 0.683 \\
\hline & $(\mathrm{CV})$ & $\neq>$ & (REER) & 0.2 & 0.655 & & $(\mathrm{CV})$ & $\neq>$ & (REER) & 3.792 & $0.011^{* *}$ \\
\hline & (REER) & $\neq>$ & $(\mathrm{CV})$ & 0.774 & 0.38 & & (REER) & $\neq>$ & $(\mathrm{CV})$ & 1.862 & 0.137 \\
\hline
\end{tabular}


Table 7. Cont.

\begin{tabular}{|c|c|c|c|c|c|c|c|c|c|c|c|}
\hline \multicolumn{10}{|c|}{ Test Values } & \multicolumn{2}{|c|}{ Test Values } \\
\hline & \multicolumn{3}{|c|}{ Null Hypothesis } & \multirow{2}{*}{$\begin{array}{c}\text { F-Value } \\
5.872\end{array}$} & \multirow{2}{*}{$\frac{p \text {-Value }}{0.016^{* *}}$} & \multirow[b]{2}{*}{ HK } & \multicolumn{3}{|c|}{ Null Hypothesis } & \multirow{2}{*}{$\begin{array}{c}\text { F-Value } \\
6.901\end{array}$} & \multirow{2}{*}{$\begin{array}{l}p \text {-Value } \\
0.001^{* * *}\end{array}$} \\
\hline TW & (IPI) & $\neq>$ & (REER) & & & & (IPI) & $\neq>$ & (REER) & & \\
\hline & (REER) & $\neq>$ & (LPI) & 0.175 & 0.676 & & (REER) & $\neq>$ & (LPI) & 0.135 & 0.874 \\
\hline & (LINT) & $\neq>$ & (REER) & 2.005 & $0.049^{* *}$ & & (LINT) & $\neq>$ & (REER) & 7.267 & $0.008^{* * *}$ \\
\hline & (REER) & $\neq>$ & (LINT) & 3.002 & $0.004^{* * *}$ & & (REER) & $\neq>$ & (LINT) & 8.803 & $0.003^{* * *}$ \\
\hline & (CPI) & $\neq>$ & (REER) & 0.027 & 0.87 & & (CPI) & $\neq>$ & (REER) & 0.051 & 0.822 \\
\hline & (REER) & $\neq>$ & $(\mathrm{CPI})$ & 0.123 & 0.727 & & (REER) & $\neq>$ & $(\mathrm{CPI})$ & 0.144 & 0.704 \\
\hline & (MS) & $\neq>$ & (REER) & 0.997 & 0.371 & & (MS) & $\neq>$ & (REER) & 1.098 & 0.359 \\
\hline & (REER) & $\neq>$ & (MS) & 0.976 & 0.379 & & (REER) & $\neq>$ & (MS) & 0.586 & 0.673 \\
\hline & $(\mathrm{CV})$ & $\neq>$ & (REER) & 1.367 & 0.244 & & $(\mathrm{CV})$ & $\neq>$ & (REER) & 0.935 & 0.394 \\
\hline & (REER) & $\neq>$ & $(\mathrm{CV})$ & 0.025 & 0.873 & & (REER) & $\neq>$ & $(\mathrm{CV})$ & 0.731 & 0.483 \\
\hline \multirow[t]{10}{*}{ JP } & (IPI) & $\neq>$ & (REER) & 0.84 & 0.36 & & & & & & \\
\hline & (REER) & $\neq>$ & (LPI) & 0 & 0.999 & & & & & & \\
\hline & (LINT) & $\neq>$ & (REER) & 8.151 & $0.000 * * *$ & & & & & & \\
\hline & (REER) & $\neq>$ & (LINT) & 1.522 & 0.221 & & & & & & \\
\hline & $(\mathrm{CPI})$ & $\neq>$ & (REER) & 0.011 & 0.915 & & & & & & \\
\hline & (REER) & $\neq>$ & $(\mathrm{CPI})$ & 0.891 & 0.346 & & & & & & \\
\hline & (MS) & $\neq>$ & (REER) & 1 & 0.37 & & & & & & \\
\hline & (REER) & $\neq>$ & (MS) & 0.276 & 0.759 & & & & & & \\
\hline & $(\mathrm{CV})$ & $\neq>$ & (REER) & 2.445 & 0.119 & & & & & & \\
\hline & (REER) & $\neq>$ & $(\mathrm{CV})$ & 0.001 & 0.971 & & & & & & \\
\hline
\end{tabular}

Notes: ${ }^{* * *}, * * *$ indicates two-tailed significance at the $1 \%, 5 \%$, and $10 \%$ levels. The symbol " $\neq>$ " means "does not Granger-cause".

\subsection{Linear Causality between EPU and REERs}

Table 8 indicates that the US EPU does not linearly Granger cause any APAC's REER, and vice versa. From Table 9, we observe that the causal relations are stronger between the CH EPU and REERs. Specifically, in addition to a significant feedback relationship detected for $\mathrm{PH}$, the results indicate a unilateral linear causal relation for another six APAC economies. Notably, the REERs from these countries Granger cause the changes in CH's EPU, and not vice versa. This finding thus implies that past CH's EPU could partially be impacted by the real estate market performance of APAC capital markets.

Table 8. Pairwise linear Granger-causality test between REERs and the US Economic Policy Uncertainty (EPU): January 1998-April 2017.

\begin{tabular}{|c|c|c|c|c|c|c|c|c|c|c|c|}
\hline & \multirow{2}{*}{\multicolumn{3}{|c|}{$\begin{array}{c}\text { US EPU } \\
\text { Null Hypothesis }\end{array}$}} & \multicolumn{2}{|c|}{ Test Values } & & & & & \multicolumn{2}{|c|}{ Test Values } \\
\hline & & & & F-Value & $p$-Value & & Null & Hypo & lesis & F-Value & $p$-Value \\
\hline \multirow[t]{4}{*}{ SG } & (REER) & $\neq>$ & (EPU) & 0.663 & 0.416 & MY & (REER) & $\neq>$ & (EPU) & 0.124 & 0.725 \\
\hline & (EPU) & $\neq>$ & (REER) & 2.29 & 0.132 & & (EPU) & $\neq>$ & (REER) & 1.217 & 0.271 \\
\hline & (REER) & $\neq>$ & (WORLD) & 2.339 & 0.128 & & (REER) & $\neq>$ & (WORLD) & 0.33 & 0.566 \\
\hline & (WORLD) & $\neq>$ & (REER) & 1.059 & 0.305 & & (WORLD) & $\neq>$ & (REER) & 2.162 & 0.143 \\
\hline \multirow[t]{4}{*}{ PH } & (REER) & $\neq>$ & (EPU) & 0.421 & 0.517 & IND & (REER) & $\neq>$ & (EPU) & 0.041 & 0.839 \\
\hline & (EPU) & $\neq>$ & (REER) & 0.007 & 0.932 & & $(\mathrm{EPU})$ & $\neq>$ & (REER) & 0.016 & 0.899 \\
\hline & (REER) & $\neq>$ & (WORLD) & 0.431 & 0.512 & & (REER) & $\neq>$ & (WORLD) & 0.039 & 0.844 \\
\hline & (WORLD) & $\neq>$ & (REER) & 5.658 & 0.018 & & (WORLD) & $\neq>$ & (REER) & 1.416 & 0.235 \\
\hline \multirow[t]{4}{*}{ TH } & (REER) & $\neq>$ & (EPU) & 0.704 & 0.402 & AU & (REER) & $\neq>$ & (EPU) & 0.01 & 0.92 \\
\hline & (EPU) & $\neq>$ & (REER) & 0.695 & 0.406 & & (EPU) & $\neq>$ & (REER) & 2.653 & 0.105 \\
\hline & (REER) & $\neq>$ & (WORLD) & 2.707 & 0.101 & & (REER) & $\neq>$ & (WORLD) & 0.667 & 0.415 \\
\hline & (WORLD) & $\neq>$ & (REER) & 0.271 & 0.603 & & (WORLD) & $\neq>$ & (REER) & 7.2 & $0.008^{* * *}$ \\
\hline \multirow[t]{4}{*}{ TW } & (REER) & $\neq>$ & (EPU) & 1.881 & 0.172 & HK & (REER) & $\neq>$ & (EPU) & 0.164 & 0.686 \\
\hline & (EPU) & $\neq>$ & (REER) & 0.703 & 0.403 & & (EPU) & $\neq>$ & (REER) & 1.381 & 0.241 \\
\hline & (REER) & $\neq>$ & (WORLD) & 1.003 & 0.318 & & (REER) & $\neq>$ & (WORLD) & 2.656 & 0.105 \\
\hline & (WORLD) & $\neq>$ & (REER) & 3.686 & $0.056^{* *}$ & & (WORLD) & $\neq>$ & (REER) & 0.068 & 0.794 \\
\hline \multirow[t]{4}{*}{ JP } & (REER) & $\neq>$ & (EPU) & 0.007 & 0.934 & & & & & & \\
\hline & (EPU) & $\neq>$ & (REER) & 1.992 & 0.16 & & & & & & \\
\hline & (REER) & $\neq>$ & (WORLD) & 0.09 & 0.765 & & & & & & \\
\hline & (WORLD) & $\neq>$ & (REER) & 0.43 & 0.513 & & & & & & \\
\hline
\end{tabular}

Notes: ${ }^{* * *}{ }^{* *}$ indicates two-tailed significance at the $1 \%$ and $5 \%$ levels. The symbol " $\neq>$ " means "does not Granger-cause". 
Table 9. Pairwise linear Granger-causality test between REERs and China EPU: January 1998-April 2017.

\begin{tabular}{|c|c|c|c|c|c|c|c|c|c|c|c|}
\hline \multirow{2}{*}{\multicolumn{4}{|c|}{$\begin{array}{l}\text { China EPU } \\
\text { Null Hypothesis }\end{array}$}} & \multicolumn{2}{|c|}{ Test Values } & & & & & \multicolumn{2}{|c|}{ Test Values } \\
\hline & & & & \multirow{2}{*}{$\frac{\text { F-Value }}{8.494}$} & \multirow{2}{*}{$\frac{p \text {-Value }}{0.004^{* * *}}$} & \multicolumn{4}{|c|}{ Null Hypothesis } & \multirow{2}{*}{$\frac{\text { F-Value }}{5.316}$} & \multirow{2}{*}{$\frac{p \text {-Value }}{0.022^{* *}}$} \\
\hline SG & (REER) & $\neq>$ & (EPU) & & & MY & (REER) & $\neq>$ & (EPU) & & \\
\hline & (EPU) & $\neq>$ & (REER) & 0.446 & 0.505 & & (EPU) & $\neq>$ & (REER) & 0.278 & 0.599 \\
\hline & (REER) & $\neq>$ & (WORLD) & 2.339 & 0.128 & & (REER) & $\neq>$ & (WORLD) & 0.33 & 0.567 \\
\hline & (WORLD) & $\neq>$ & (REER) & 1.059 & 0.305 & & (WORLD) & $\neq>$ & (REER) & 2.162 & 0.143 \\
\hline \multirow[t]{4}{*}{ PH } & (REER) & $\neq>$ & (EPU) & 5.333 & 0.022 ** & IND & (REER) & $\neq>$ & (EPU) & 0.472 & 0.493 \\
\hline & (EPU) & $\neq>$ & (REER) & 2.933 & 0.088 & & (EPU) & $\neq>$ & (REER) & 1.177 & 0.279 \\
\hline & (REER) & $\neq>$ & (WORLD) & 0.432 & 0.512 & & (REER) & $\neq>$ & (WORLD) & 0.039 & 0.844 \\
\hline & (WORLD) & $\neq>$ & (REER) & 5.658 & $0.018^{* *}$ & & (WORLD) & $\neq>$ & (REER) & 1.416 & 0.235 \\
\hline \multirow{4}{*}{ TH } & (REER) & $\neq>$ & (EPU) & 3.37 & $0.068 *$ & AU & (REER) & $\neq>$ & (EPU) & 8.822 & $0.003^{* * *}$ \\
\hline & (EPU) & $\neq>$ & (REER) & 0.115 & 0.735 & & (EPU) & $\neq>$ & (REER) & 0.446 & 0.505 \\
\hline & (REER) & $\neq>$ & (WORLD) & 2.707 & 0.101 & & (REER) & $\neq>$ & (WORLD) & 0.667 & 0.415 \\
\hline & (WORLD) & $\neq>$ & (REER) & 0.271 & 0.603 & & (WORLD) & $\neq>$ & (REER) & 7.2 & $0.008^{* * *}$ \\
\hline \multirow[t]{4}{*}{ TW } & (REER) & $\neq>$ & (EPU) & 1.727 & 0.19 & HK & (REER) & $\neq>$ & (EPU) & 13.25 & $0.000^{* * *}$ \\
\hline & (EPU) & $\neq>$ & (REER) & 0.377 & 0.54 & & (EPU) & $\neq>$ & (REER) & 1.399 & 0.238 \\
\hline & (REER) & $\neq>$ & (WORLD) & 1.003 & 0.318 & & (REER) & $\neq>$ & (WORLD) & 2.656 & 0.105 \\
\hline & (WORLD) & $\neq>$ & (REER) & 3.686 & $0.056 * *$ & & (WORLD) & $\neq>$ & (REER) & 0.068 & 0.794 \\
\hline \multirow{4}{*}{ JP } & (REER) & $\neq>$ & (EPU) & 5.33 & $0.022 * *$ & & & & & & \\
\hline & (EPU) & $\neq>$ & (REER) & 0.028 & 0.866 & & & & & & \\
\hline & (REER) & $\neq>$ & (WORLD) & 0.09 & 0.765 & & & & & & \\
\hline & (WORLD) & $\neq>$ & (REER) & 0.43 & 0.513 & & & & & & \\
\hline
\end{tabular}

Notes: ${ }^{* * *}, * *, *$ indicates two-tailed significance at the $1 \%, 5 \%$, and $10 \%$ levels. The symbol " $\neq>$ " means "does not Granger-cause".

During the crisis period (results not reported to conserve space), the US EPU Granger causes the REERs of the developed APAC nations. During the post-crisis period, the REERs of SG, HK, and IN Granger causes the US EPU, significant at the $10 \%$ level. Thus, the US EPU could be sensitive to some foreign market activities. For $\mathrm{CH}$, its EPU Granger causes the REERs of five nations each in both sub-periods significantly. During the crisis period, the causal effects were among the developed economies, whereas, in the post-crisis period, the causal relations happened between $\mathrm{CH}^{\prime} \mathrm{s}$ EPU and the REERs of the ASEAN5 nations, an indication of a closer real estate market integration among the ASEAN5 nations and $\mathrm{CH}$ in recent years.

\subsection{Nonlinear Granger Causal Relations between APAC Nations' REERs and US/CH Macroeconomic Conditions/EPU}

The full-period test results of the pairwise non-linear causality tests between the nine APAC REERs and the US/CH macroeconomic variables are reported in Tables 10 and 12, respectively.

Notably, US conditional variance (CV) non-Granger causes the REERs in all nine APAC nations, indicating that the US real estate market volatility is a key causal macro-factor. Specifically, the HJ and $\mathrm{T} 2$ results reveal there are four pairs of nonlinear Granger bidirectional causality interactions between the US CV and REERs in the four APAC developed markets (US-SG, US-AU, US-JP, and US-HK). Additionally, there are other instances where other US macroeconomic variables nonlinearly Granger cause these four markets' REERs. These significant causal results are consistent with the expectation that US macroeconomic conditions continue to maintain a dominant influence on the APAC developed real estate capital markets in the era of real estate asset securitization. Turning our attention to $\mathrm{CH}$, there are six pairs of non-linear feedback relationship between the $\mathrm{CH}^{\prime} \mathrm{S} \mathrm{CV}$ and APAC's REERs (CH-SG, CH-TH, CH-MA, CH-AU, CH-TW, and CH-HK). Additionally, there are several other cases of one-way directional relationships between $\mathrm{CH}^{\prime}$ s macro-factors and REERs in some APAC nations, implying that $\mathrm{CH}^{\prime}$ s macroeconomic conditions are equally strong in influencing the APAC real estate market performance. 
Table 10. Pairwise non-linear causality test between REERs and the US macroeconomic variables: January 1998-April 2017.

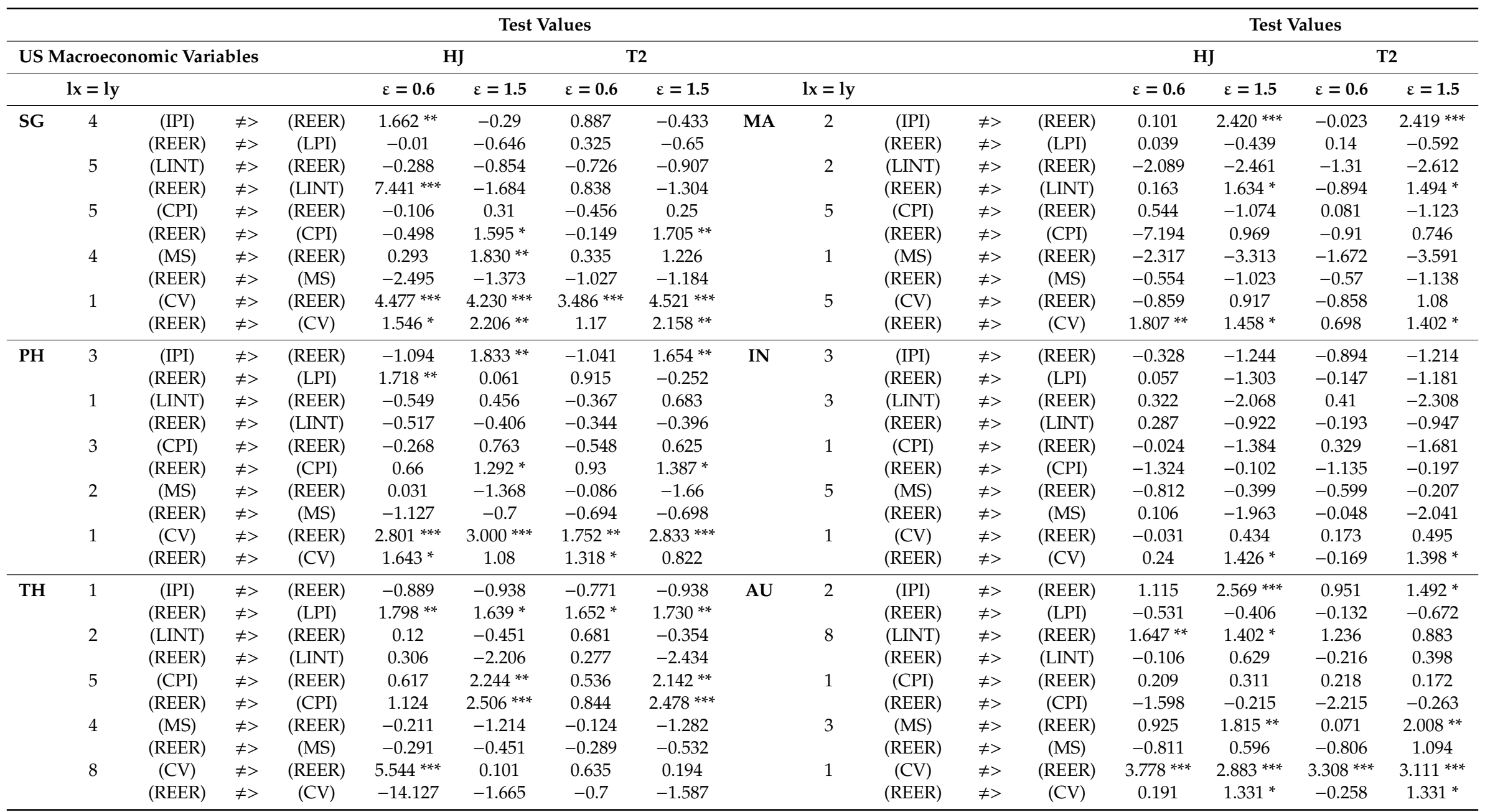


Table 10. Cont.

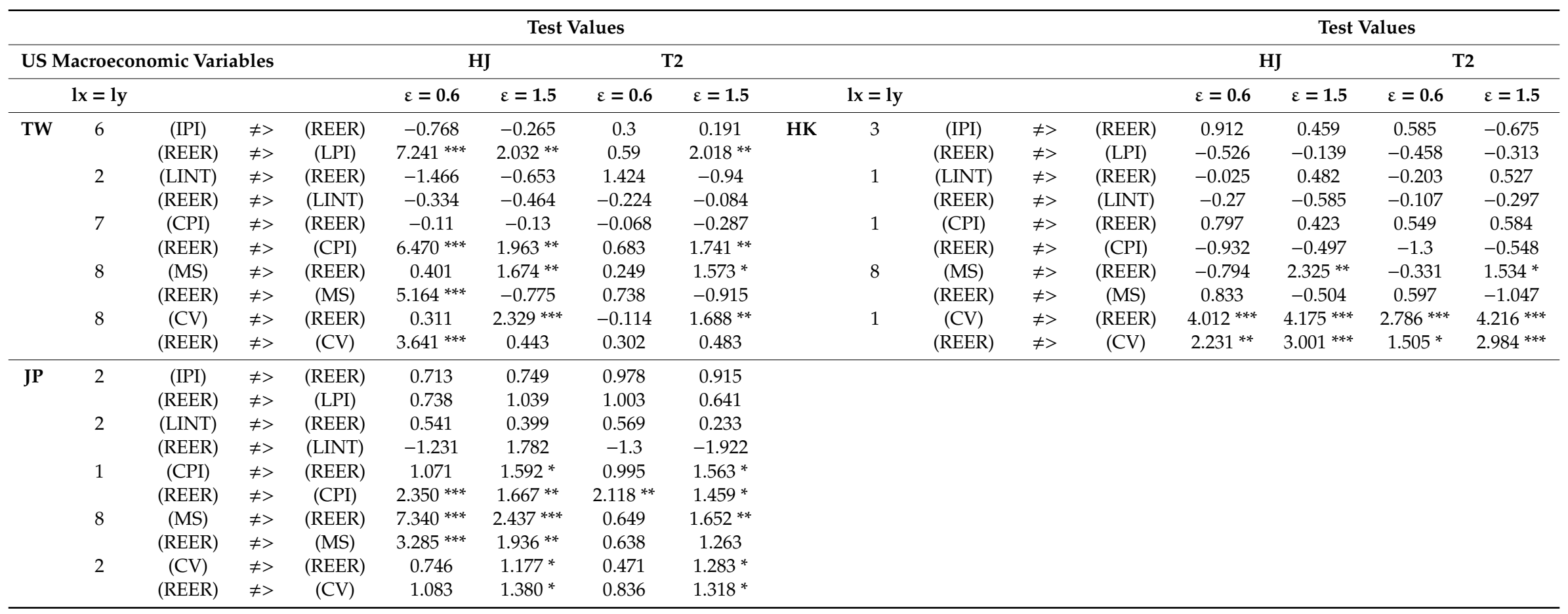

Notes: The results are based on the estimated standardized residual series obtained from the VAR models. Lx = Ly denote the number of lags on the residual series for length scales of 0.6 and 1.5. The symbol " $\neq>$ " means "does not Granger-cause". Both the nonlinear Hiemstra and Jones (1994) (denoted by HJ test), as well as Diks and Panchenko (2006) tests (denoted by T2 test) are investigated. ${ }^{* *}, * *$ and $*$ indicaterejection of the null hypothesis of nonlinear Granger noncausality at the 1,5 and 10 percent significance level. 
Table 11. Non-linear causality test between REERs and the China macroeconomic variables: January 1998-April 2017.

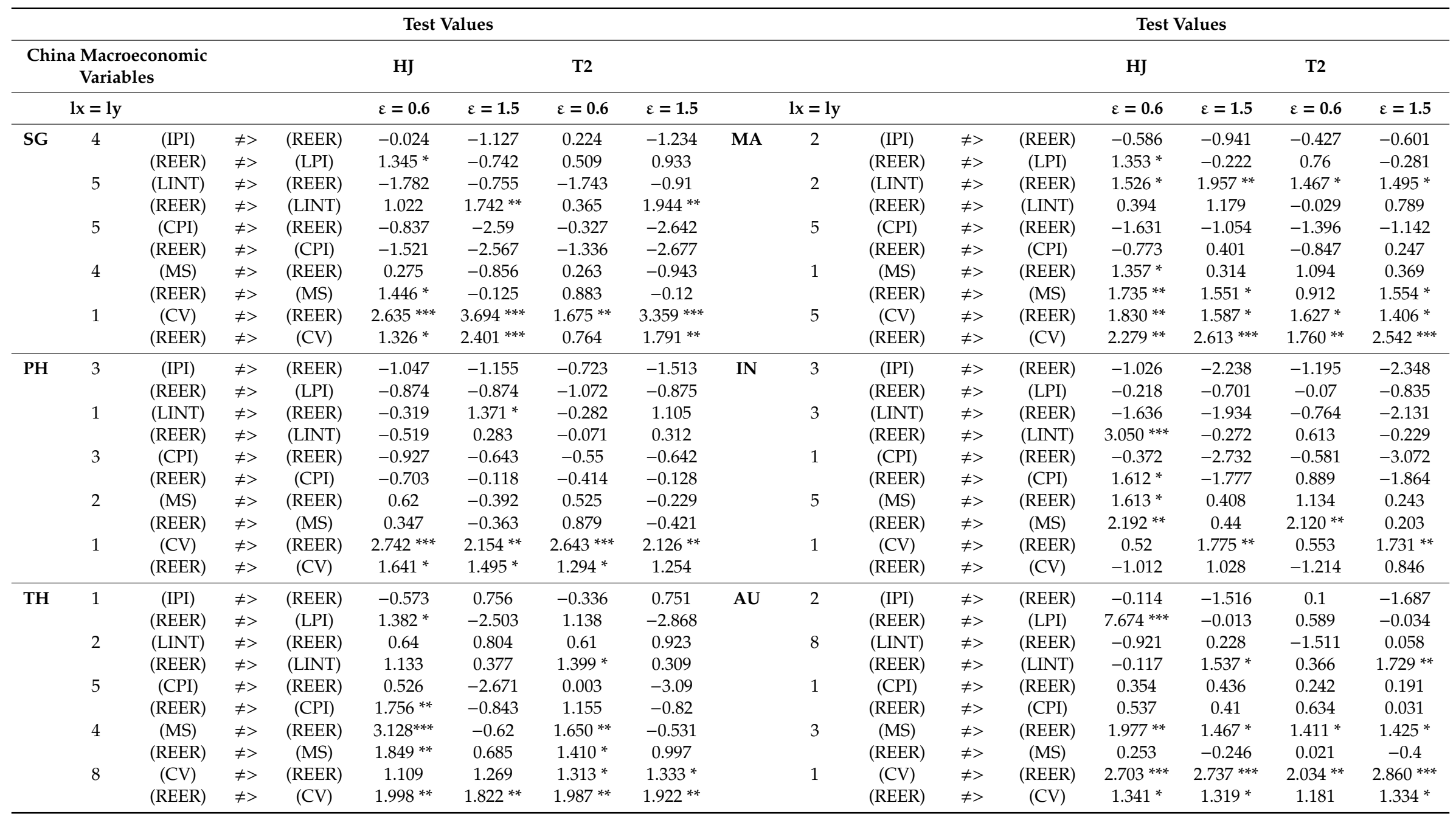


Table 12. Non-linear causality test between REERs and the China macroeconomic variables: January 1998-April 2017.

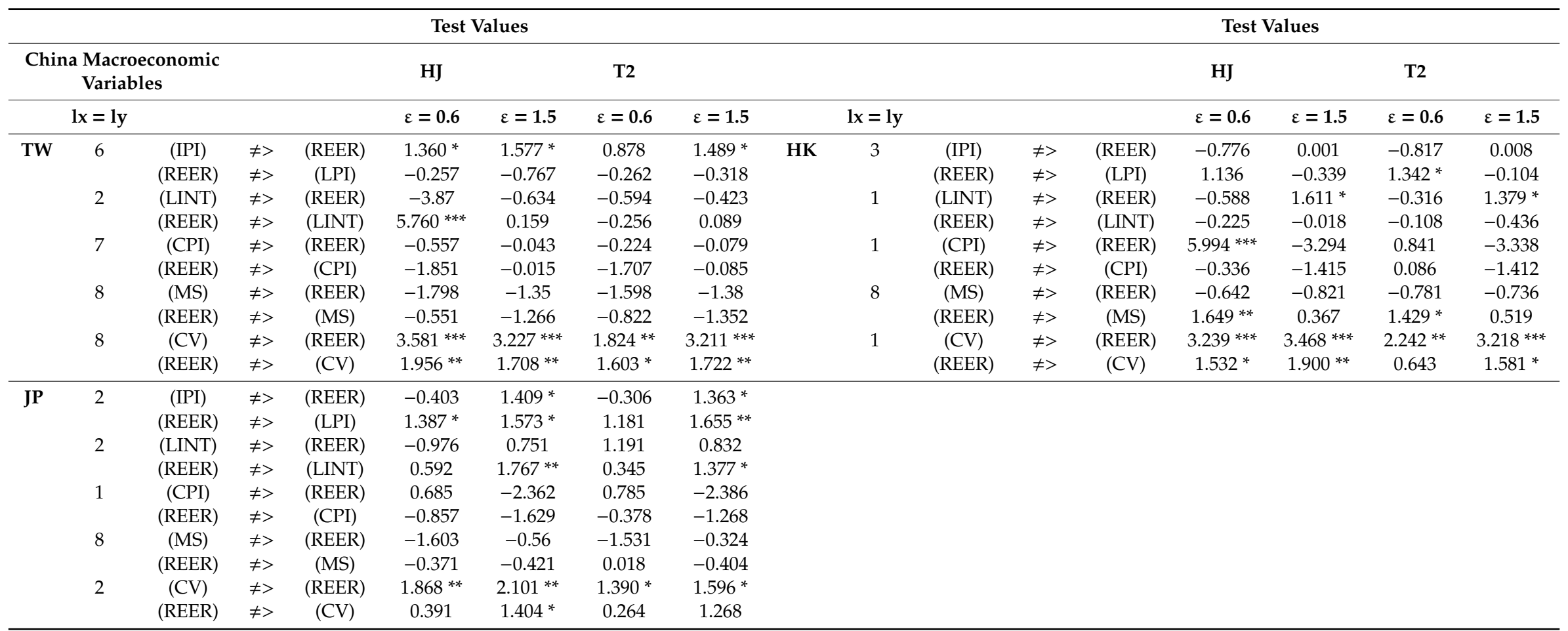

Notes: The results are based on the estimated standardized residual series obtained from the VAR models. Lx = Ly denote the number of lags on the residual series for length scales of 0.6 and 1.5. The symbol " $\neq>$ " means "does not Granger-cause". Both the nonlinear Hiemstra and Jones (1994) (denoted by HJ test), as well as Diks and Panchenko (2006) tests (denoted by T2 test) are investigated. ${ }^{* * *}, * *$ and ${ }^{*}$ indicate $\backslash$ rejection of the null hypothesis of nonlinear Granger noncausality at the 1,5 and 10 percent significance level. 
With regard to the causal impact of EPU, the results (not reported in order to conserve space) indicate the US EPU Granger causes the REERs in five (out of nine) of the APAC countries (SG, MA, IN, AU, and HK), while CH EPU Granger causes the REERs in three (out of nine) of the APAC nations (IN, TH, and JP). Interestingly, none of the APAC nations' REER is caused by both the US and CH's EPU, indicating that the causal effects of US and CH's EPU may be unique and that every APAC real estate market is only causally influenced by either the US EPU or CH EPU only, at least within the period of analysis.

To conclude, in the context that non-linear Granger causality tests (both HJ and T2 tests) generally have higher power against linear relationships, our overall analysis clearly supports a non-linear Granger modelling of the US/CH macroeconomic relationship and other APAC nations' REERs we examined in this study. Both the US and $\mathrm{CH}$ are quite interactive in their non-linear causal linkages between their macroeconomic conditions and APAC nations' REERs.

\subsection{Impulse Response of Macroeconomic Factors/EPU on APAC Nations' REERs}

Impulse responses provide information about how a dependent variable (REERs) will respond to the shocks applied by individual impulse variables. In this section, impulse responses from the US and $\mathrm{CH}$ macroeconomic shocks/EPU shocks are plotted together to provide a comparative analysis of the response patterns. The results obtained from the GIRF on each variable provides the direction, the magnitude and behavior of the responses over a fixed period. In each of the individual impulse response graphs in Figures 2-7, the $y$-axis denotes the magnitude of the response that was recorded for each variable, and the $x$-axis denotes the period on which each variable responded. The IRF graphs are derived from the VAR GIRFs of the nine APAC REERs to innovations of one standard deviation. Finally, lags were selected according to the Schwarz information criterion. Data were monthly and ran from January 1998 to April 2017.

In Figure 2, where the IRF graphs for the IPI of the US and $\mathrm{CH}$ are shown, we observe that the shocks in the US IPI significantly affect the REERs in all APAC nations. These shocks exert a positive impact such that an increase in one standard deviation is associated with a sharp increase in the REERs As for the shocks from the CH IPI, the responses of the APAC markets are generally milder and insignificant in some cases as compared to the US, with some exceptions. Finally, the IRFs from the US/CH IPI have long-lasting effects, with the responses fading off only after the sixth month (except for Taiwan, which lasts even longer).

Figure 3 displays the IRF graphs for the LINT. With some exceptions, CH LTINT is capable of generating volatile shocks compared to that of US. These shocks exert a positive impact such that an increase in one standard deviation of CH LINT shocks is associated with a sharp increase in APAC's REERs. The responses from the US LTINT tends to lag CH LTINT by one to two months, implying that the money markets in the US may be more efficient than $\mathrm{CH}$ in capturing the changes in the LINT on the APAC real estate capital markets.

Figure 4 displays the IRF graphs for the variable CPI. We observe that the US CPI shocks may result in a sharply negative response from the APAC real estate markets. In general, the US inflation shocks on the ASEAN5 nations is highly sensitive and of considerable magnitude, implying that the US inflation shocks continue to have a dominant and lasting effect on ASEAN5 real estate markets, whereas the $\mathrm{CH}$ inflation shocks have relatively little impact on the APAC nations' REERs, as observed.

In Figure 5, we observe that the shocks from the $M S$ variable exert a negative impact on the APAC real estate markets. Comparatively, the responses from Indonesia (IN) and Australia (AU) are exceptionally sensitive to the shocks from both the US and CH MS shocks. The MS shocks from the US lag that of $\mathrm{CH}$ for about one period, thereby implying that shocks from $\mathrm{CH}^{\prime} \mathrm{s} M S$ are less impactful as compared to that of US. This is further consistent with the expectation that the US dollar is the most influential global currency reserved under the International Monetary Fund (IMF). 


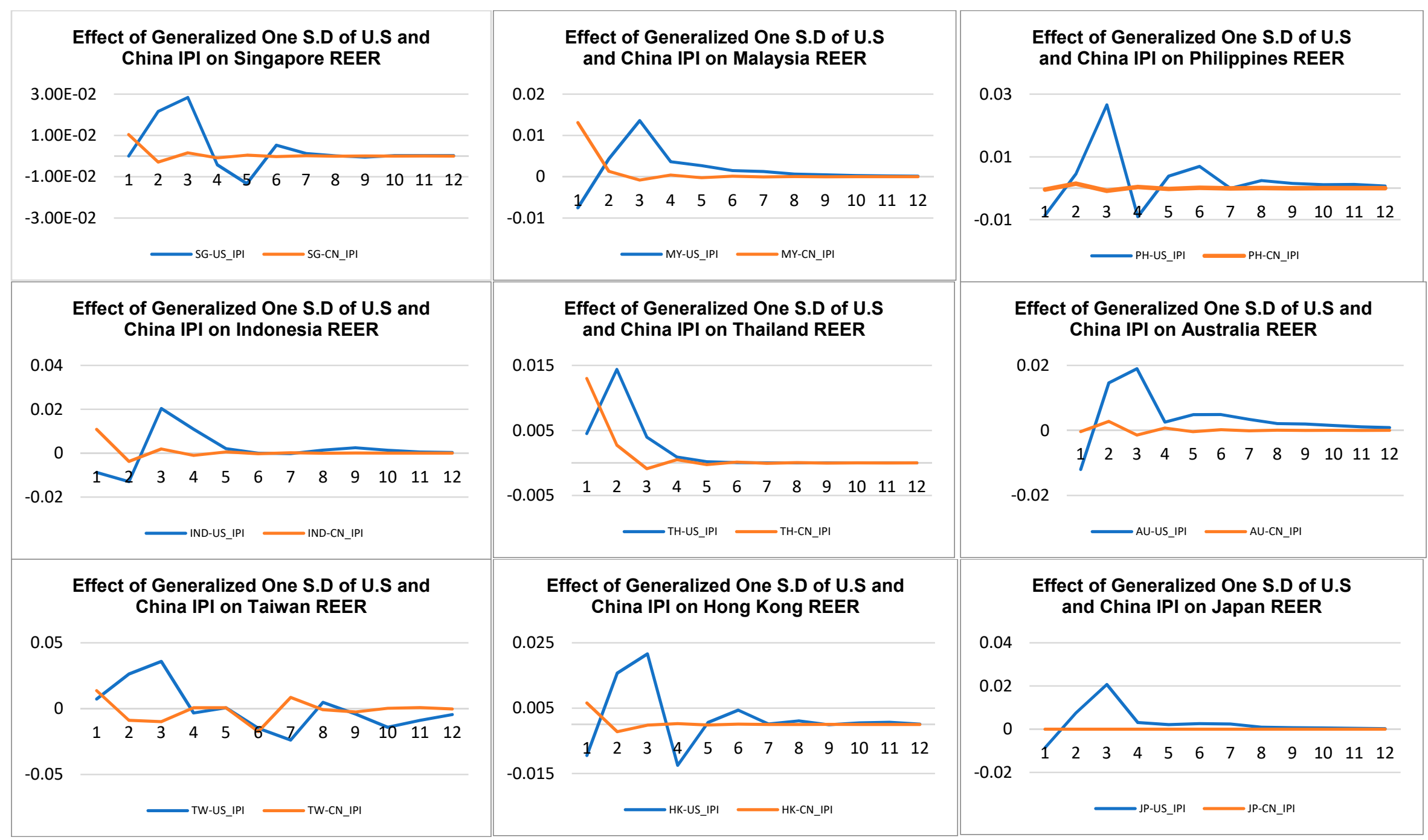

Figure 2. VAR estimations of Impact of Innovations of one standard deviation in US and China industrial production index (IPI) on the APAC REERs. 


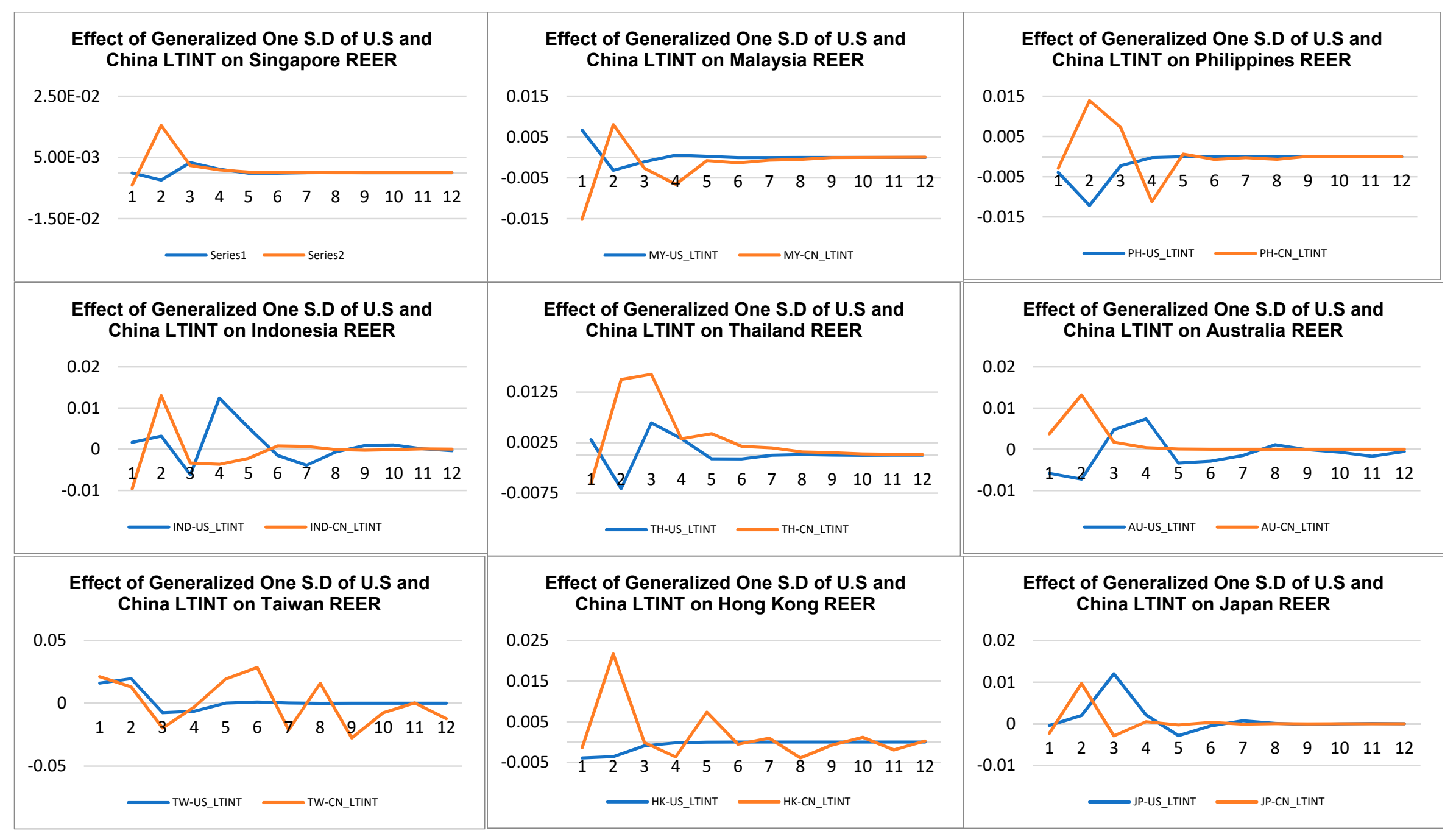

Figure 3. VAR estimations of the impact of innovations of one standard deviation in the US and China long-term interest rate (LNINT) on the APAC REERs. 


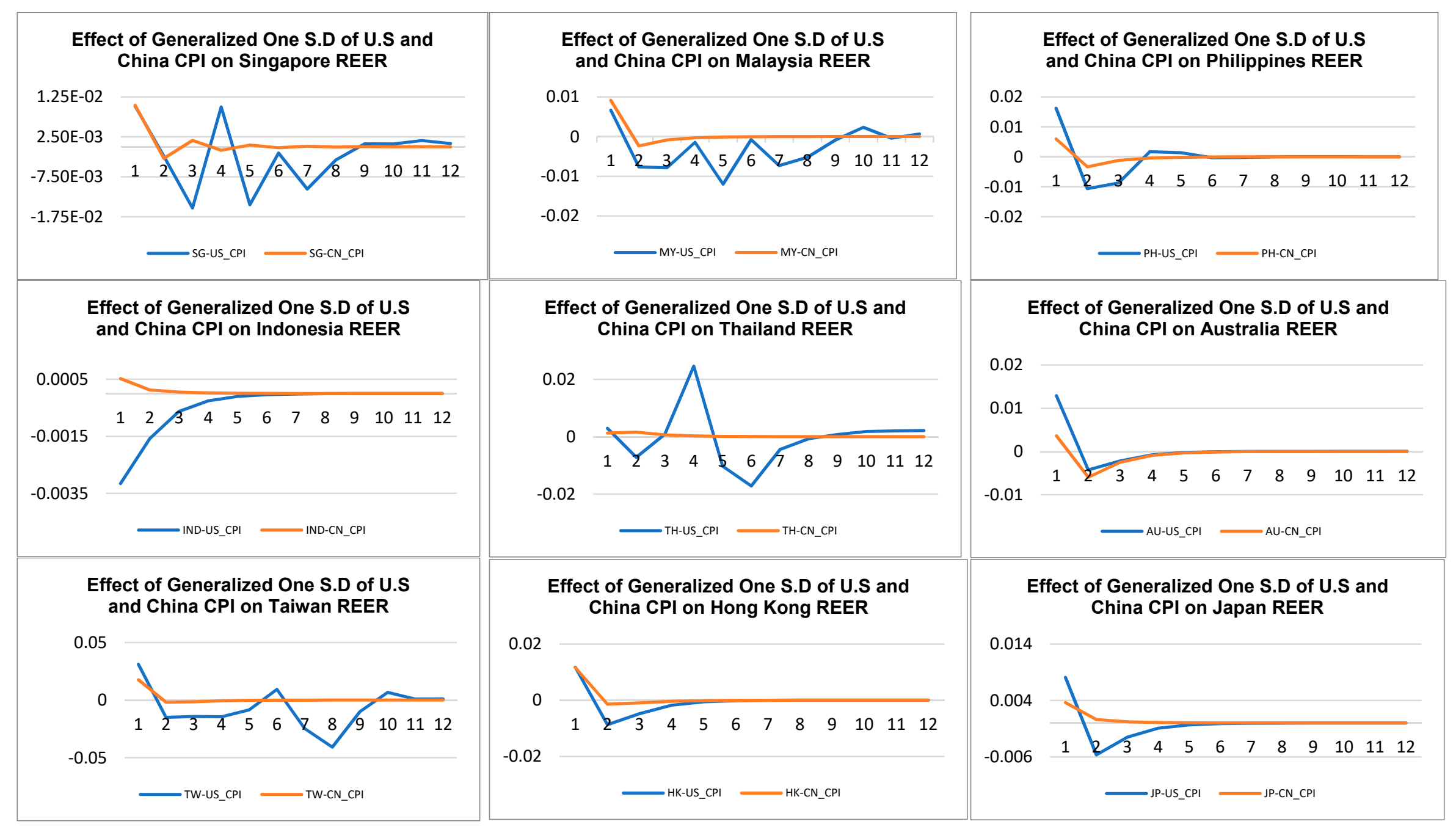

Figure 4. VAR estimations of the impact of innovations of one standard deviation in the US and China consumer price index (CPI) on the APAC REERs. 


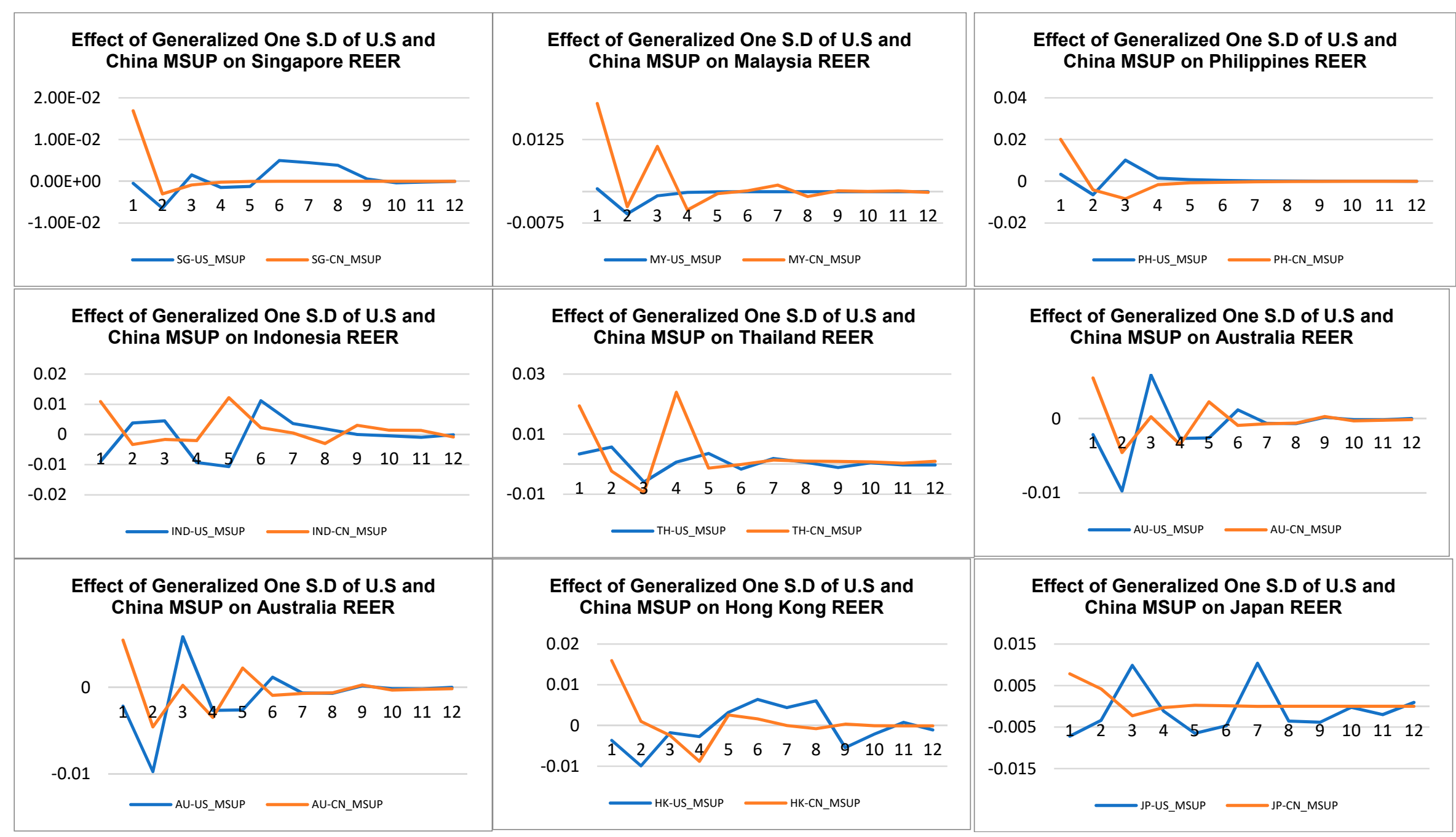

Figure 5. VAR estimations of the impact of innovations of one standard deviation in the US and China money supply aggregate (MS) on the APAC REERs. 


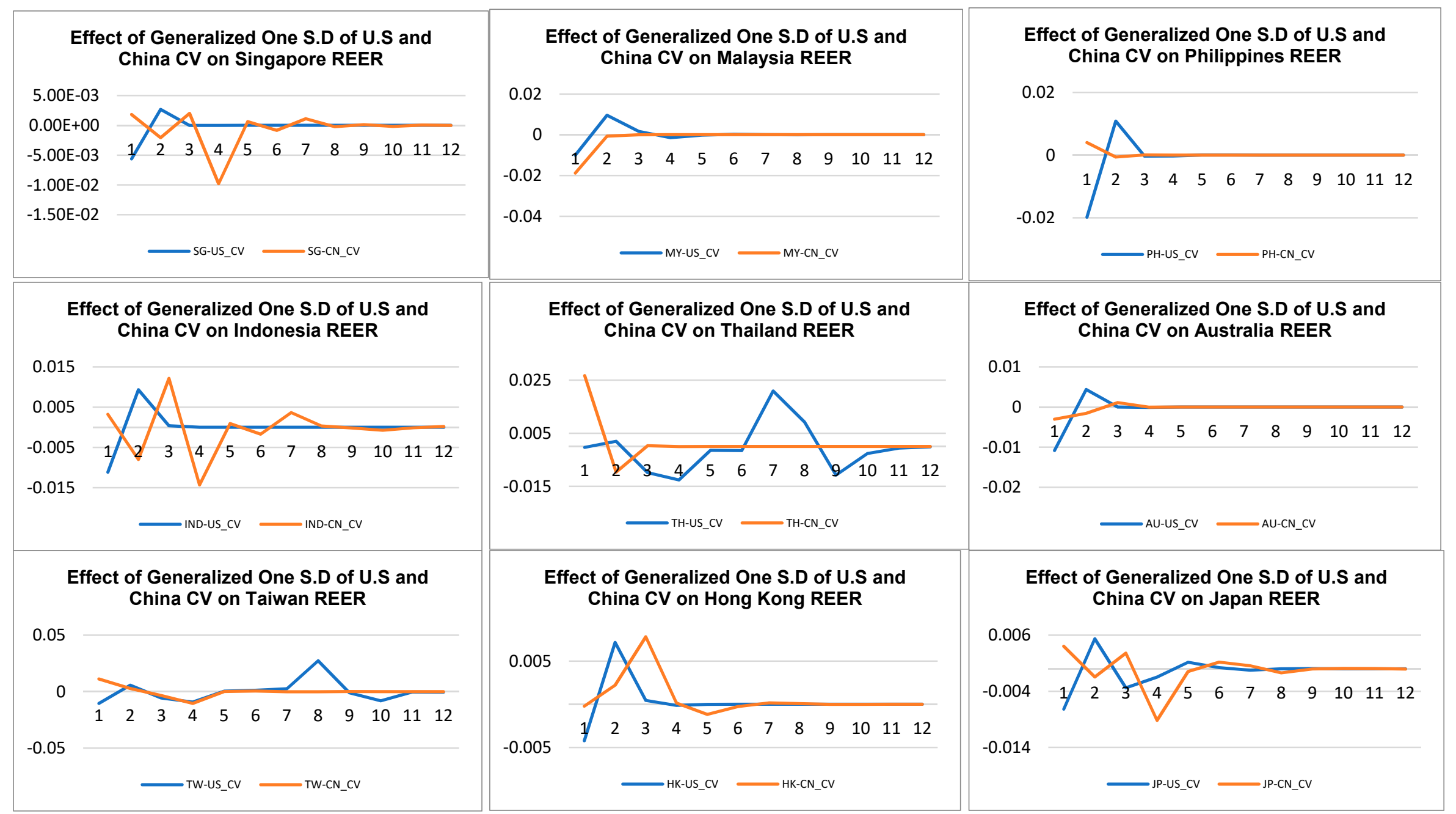

Figure 6. VAR estimations of the impact of innovations of one standard deviation in the US and China conditional variance (CV) on the APAC REERs. 


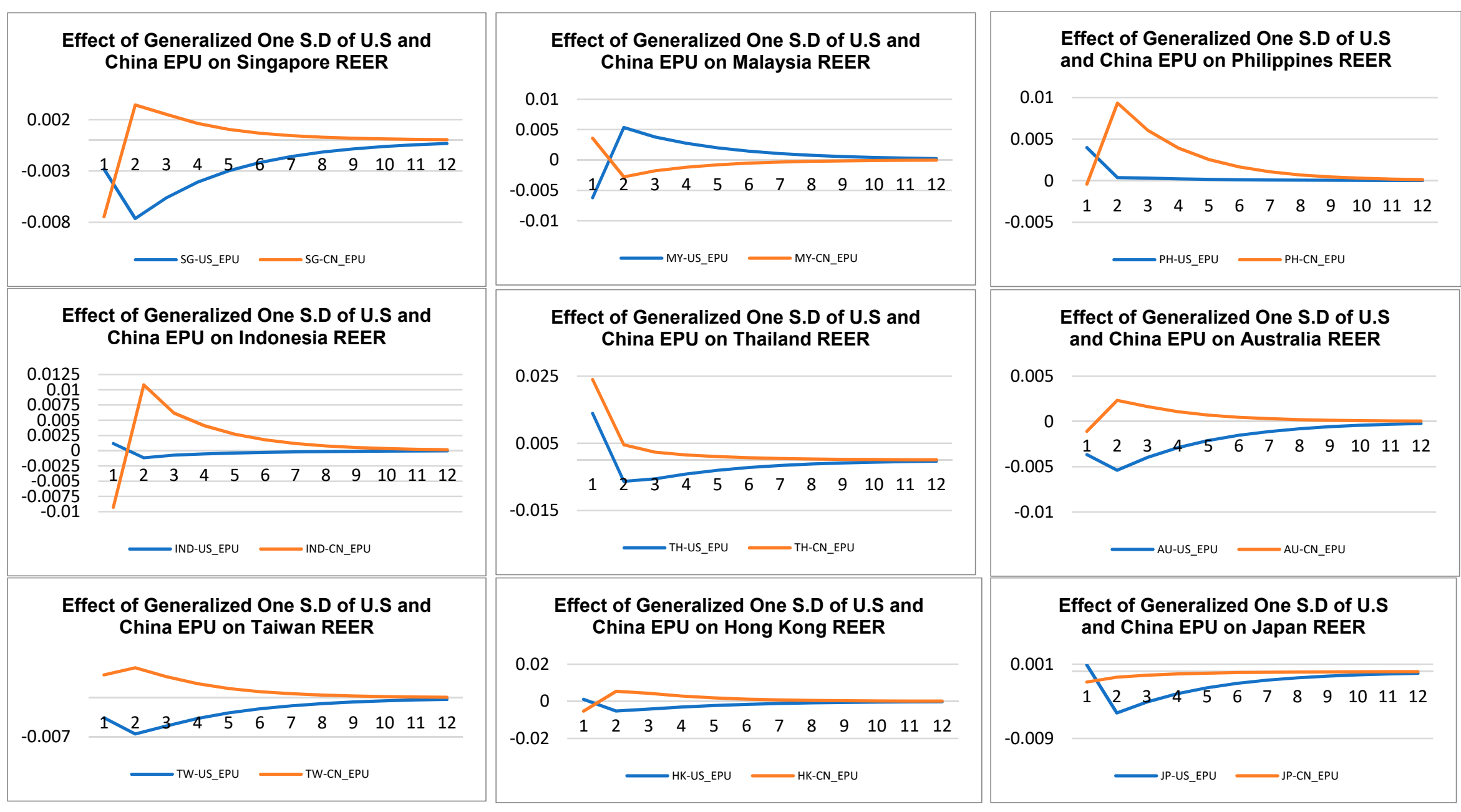

Figure 7. VAR estimations of impact of innovations of one standard deviation in the US and China economic policy uncertainty (EPU) on the APAC REERs. 
In Figure 6, where the IRF graphs for the $C V$ (volatility) variable is displayed, we observe that both the US and $\mathrm{CH} C V$ exert a negative impact on the APAC markets. Moreover, the responses from $\mathrm{SG}$, IN, and JP are highly sensitive to the shocks from the US/CH CV. One other observation we made is the shocks from the US CV resulted in a delayed response on both the REERs of TH and TW, implying that the effects of $C V$ on the APACs can be immediate or lagged in the short or long run.

Finally, Figure 7 displays the IRF graphs for the EPU shocks. It appears that the responses from the US and CH EPU shocks diverge among the ASEAN5 nations. Specifically, the responses from the $\mathrm{CH} E P U$ shocks have a positive relationship with the REERs, which run contrary to the expectation that the EPU shocks negatively affects both domestic and foreign economies. Finally, the US and $\mathrm{CH}$ $E P U$ have quite similar levels of shock impact on the APAC real estate markets examined.

\section{Conclusions}

The novelty of this study is that it contributes to the literature gap on the impact of foreign macroeconomic variables (including EPU) on real estate market performance. The findings from this study will provide value to investors, policy makers, and academia in better understanding the dynamic relationship between macroeconomic changes/uncertainty and domestic/foreign financial markets. Using a unique set of APAC real estate excess return data and $\mathrm{CH} / \mathrm{US}$ economic data from January 1998 to April 2017 and several econometric tests, the main results are:

1. Both US and China macroeconomic factors and economic policy uncertainty do not have any significant contemporaneous impact on APAC real estate market excess returns. These results agree with the conventional wisdom that foreign macroeconomic factors have weaker correlations with real estate returns, as compared to their domestic counterparts.

2. The US and China macroeconomic factors and economic policy uncertainty Granger cause the APAC real estate market excess returns, although the causal effects are generally more prominent among the US macroeconomic factors using nonlinear causality tests. Additional findings affirm the expectation that China has an increasing influence over the APAC real estate markets examined over the short run while the US is still maintaining its dominance in the regional real estate markets in long run.

3. The IRF analysis indicates that the shock response from the real estate excess returns in the ASEAN5 (part of APAC) is sensitive to both the US and China macroeconomic variables. In the context of regional globalization and financial market integration, ASEAN5 real estate markets are expected to be more interdependent with the US and China real estate markets.

Finally, the results reported in this paper have some portfolio and policy implications. Whilst the weak explanatory power of the US macroeconomic fundamentals and economic policy uncertainty suggests that APAC real estate markets are still largely impacted by local factors, the results also imply that diversification can become more difficult for those investors who invest in APAC real estate markets. This is because not only do the changes in economic fundamentals/economic policy uncertainty in the US and China affect real estate markets in their own countries, these changes also affect real estate market excess return performance in the APAC nations as well. In the context that a high degree of economic and financial integration has affected the interdependent level of international financial markets, Asian-Pacific securitized real estate markets' performances are also impacted by global shocks.

Author Contributions: K.H.L. initiated the idea, overall research strategy and methodology for this article. He edited the final paper for submission. Y.H. supervised and guided data collection and screening, as well as checked thoroughly on the estimated results. Finally, K.L.H. performed data analysis and development of findings. He wrote the draft for this paper.

Funding: This research received no external funding.

Conflicts of Interest: The authors declare no conflict of interest. 


\section{References}

Alam, Naushad. 2017. Analysis of the impact of select macroeconomic variables on the Indian stock market: A heteroscedastic cointegration approach. Business and Economic Horizons 13: 119-27. [CrossRef]

Araújo, Eurilton. 2009. Macroeconomic shocks and the co-movement of stock returns in Latin America. Emerging Markets Review 10: 331-44. [CrossRef]

Baek, Ehung Gi, and William A. Brock. 1992. A General Test for Nonlinear Granger Causality: Bivariate Model. Madison Working Paper. Ames: Iowa State Unoversity.

Bailliu, Jeannine, and Patrick Blagrave. 2010. The Transmission of Shocks to the Chinese Economy in a Global Context: AModel-Based Approach. Working Paper 2010-07, July. Ottawa: Bank of Canada.

Baker, Nicholas Bloom, and Steven J. Davis. 2016. Measuring economic policy uncertainty. The Quarterly Journal of Economics 131: 1593-636. [CrossRef]

Binswanger, Mathias. 2004. How important are fundamentals? Evidence from a structural VAR model for the stock markets in US, Japan and Europe. Journal of International Financial Markets Institutions and Money 14: 185-201. [CrossRef]

Bloom, Nicholas. 2009. The impact of uncertainty shocks. Econometrica 77: 623-85.

Chan, Kam C., Benton E. Gup, and Ming-Shiun Pan. 1992. An Empirical Analysis of Stock Prices in Major Asian Markets and the United States. The Financial Review 27: 289-307. [CrossRef]

Chen, Nai-Fu, Richard Roll, and Stephen A. Ross. 1986. Economic forces and the stock market. Journal of Business 59: 383-403. [CrossRef]

Chen, Jian, Fuwei Jiang, and Guoshi Tong. 2016. Economic Policy Uncertainty in China and Stock Market Expected Returns. Accounting E Finance 57: 1265-86.

Cheng, Hwahsin, and John L. Glascock. 2006. Stock market linkages before and after the Asian financial Crisis: Evidence from three Greater China economic area stock markets and the US. Review of Pacific Basin Financial Markets and Policies 9: 297-306. [CrossRef]

Cheng, Andy, and Iris Wing Han Yip. 2017. China's macroeconomic fundamentals on stock market volatility: Evidence from Shanghai and Hong Kong. Review of Pacific Basin Financial Markets and Policies 20: 1-57. [CrossRef]

Diks, Cees, and Valentyn Panchenko. 2006. A new statistic and practical guidelines for nonparametric Granger causality testing. Journal of Economic Dynamics and Control 30: 1647-69. [CrossRef]

Donadelli, Michael. 2015. Asian stock markets, US economic policy uncertainty and US macro shocks. New Zealand Economic Papers 49: 103-33. [CrossRef]

Donadelli, Michael, and Lauren Persha. 2014. Understanding emerging market equity risk premia: Industries, governance and macroeconomic policy uncertainty. Research in International Business and Finance 30: 284-309. [CrossRef]

Donadelli, Michael, and Lorenzo Prosperi. 2012. On the role of liquidity in emerging markets stock prices. Research in Economics 66: 320-48. [CrossRef]

Eickmeier, Sandra, and Markus Kuhnlenz. 2013. China's Role in Global Inflation Dynamics. Bundesbank Discussion Paper 07/2013. Cambridge: Cambridge University Press.

Fama, Eugene F. 1981. Stock returns, real activity, inflation and money. American Economic Review 71: 545-65.

Fung, Hung-Gay, Guoming Huang, Qingfeng Liu, and Xiaoqin Shen. 2006. The development of the real estate industry in China. The Chinese Economy 39: 84-102. [CrossRef]

Granger, Clive W. J. 1969. Investigating causal relations by econometric models and cross-spectral methods. Econometrica 37: 424-38. [CrossRef]

Hiemstra, Craig, and Jonathan D. Jones. 1994. Testing for linear and nonlinear Granger causality in the stock price-volume relation. Journal of Finance 49: 1639-64.

Hui, Eddie C. M., and Ivan M. H. Ng. 2012. Wealth effect, credit price effect, and the relationships between Hong Kong property market and stock market. Property Management 30: 255-73. [CrossRef]

International Monetary Fund. 2017. Regional Economic Outlook: Asia Pacific: Preparing for Choppy Seas, May. Washington: International Monetary Fund.

Johansson, Anders C., and Christer Ljungwall. 2009. Spillover effects among the Greater China stock markets. World Development 37: 839-51. [CrossRef] 
Li, Xiao-Lin, Mehmet Balcilar, Rangan Gupta, and Tsangyao Chang. 2015. The causal relationship between economic policy uncertainty and stock returns in China and India: Evidence from a bootstrap rolling window approach. Emerging Markets Finance and Trade 52: 674-89. [CrossRef]

Ling, David C., and Andy Naranjo. 2002. Commercial real estate return performance: A cross-country analysis. Journal of Real Estate Finance and Economics 24: 119-42. [CrossRef]

Liow, Kim Hiang, and Alastair Adair. 2009. Do Asian real estate companies add value to investment portfolio? Journal of Property Investment \& Finance 27: 42-64.

Narayan, Paresh Kumar, and Seema Narayan. 2012. Do US macroeconomic conditions affect Asian stock market returns? Journal of Asian Economics 23: 669-79. [CrossRef]

Nikkinen, Jussi, and Petri Sahlstrom. 2004. Scheduled domestic and US macroeconomic news and stock valuation in Europe. Journal of Multinational Financial Management 14: 201-15. [CrossRef]

Nishimura, Yusaku, and Ming Men. 2010. The paradox of China's international stock market co-movement: Evidence from volatility spillover effects between China and G5 stock markets. Journal of Chinese Economic and Foreign Trade Studies 3: 235-53. [CrossRef]

Okunev, John, Patrick Wilson, and Ralf Zurbruegg. 2000. The causal relationship between real estate and stock markets. The Journal of Real Estate Finance and Economics 21: 251-61. [CrossRef]

Pesaran, H. Hashem, and Yongcheol Shin. 1998. Generalized impulse response analysis in linear multivariate models. Economics Letters 58: 17-29. [CrossRef]

Roll, Richard, and Stephen A. Ross. 1980. An empirical investigation of the arbitrage pricing theory. Journal of Finance 35: 1073-103. [CrossRef]

Ross, Stephen A. 1976. The arbitrage pricing theory of capital asset pricing. Journal of Economic Theory 13: 341-60. [CrossRef]

Schindler, Felix. 2011. Long-term benefits from investing in international securitized real estate. International Real Estate Review 14: 27-60.

Sharma, Subhash C., and Praphan Wongbangpo. 2002. Stock market and macroeconomic fundamental dynamic interactions: ASEAN-5 countries. Journal of Asian Economics 13: 27-51.

Sum, Vichet. 2013. The ASEAN Stock Market Performance and Economic Policy Uncertainty in the United States. Economic Papers: Journal of Applied Economics and Policy 32: 512-21. [CrossRef]

Zheng, Yongnianand, and Chi Zhang. 2016. The Belt and Road Initiative and China's Grand Diplomacy. China and the World 1: 309-31.

(C) 2019 by the authors. Licensee MDPI, Basel, Switzerland. This article is an open access article distributed under the terms and conditions of the Creative Commons Attribution (CC BY) license (http://creativecommons.org/licenses/by/4.0/). 